\title{
A dynamic mechanistic model of lactic acid metabolism in the rumen
}

\author{
J. A. N. Mills, ${ }^{\star}$ L. A. Crompton, ${ }^{\star}$ J. L. Ellis, $\nmid \ddagger^{1}$ J. Dijkstra,† A. Bannink,§ S. Hook, † C. Benchaar,\# \\ and J. France \\ ${ }^{*}$ The University of Reading, Centre for Dairy Research, Department of Agriculture, Reading, RG6 6AT, UK \\ †Animal Nutrition Group, Wageningen University, 6708 WD, Wageningen, the Netherlands \\ $\ddagger$ Centre for Nutrition Modelling, Animal and Poultry Science, University of Guelph, Guelph, ON N1G 2W1, Canada \\ §Wageningen UR Livestock Research, 8219 PH, Lelystad, the Netherlands \\ \#Dairy and Swine Research and Development Centre, Agriculture and Agri-Food Canada, Sherbrooke, QC J1M 0C8, Canada
}

\begin{abstract}
Current feed evaluation systems for ruminants are too imprecise to describe diets in terms of their acidosis risk. The dynamic mechanistic model described herein arises from the integration of a lactic acid (La) metabolism module into an extant model of whole-rumen function. The model was evaluated using published data from cows and sheep fed a range of diets or infused with various doses of La. The model performed well in simulating peak rumen La concentrations (coefficient of determination $=0.96$; root mean square prediction error $=16.96 \%$ of observed mean), although frequency of sampling for the published data prevented a comprehensive comparison of prediction of time to peak La accumulation. The model showed a tendency for increased La accumulation following feeding of diets rich in nonstructural carbohydrates, although lesssoluble starch sources such as corn tended to limit rumen La concentration. Simulated La absorption from the rumen remained low throughout the feeding cycle. The competition between bacteria and protozoa for rumen La suggests a variable contribution of protozoa to total La utilization. However, the model was unable to simulate the effects of defaunation on rumen La metabolism, indicating a need for a more detailed description of protozoal metabolism. The model could form the basis of a feed evaluation system with regard to rumen La metabolism.
\end{abstract}

Key words: lactic acid, rumen, mechanistic model

\section{INTRODUCTION}

For many years researchers have recognized the importance of lactic acid (La) as an intermediary during the fermentation of NSC in the rumen (Phillipson and McAnally, 1942; Elsden, 1945; Waldo and Schultz,

Received October 9, 2013.

Accepted December 20, 2013.

${ }^{1}$ Corresponding author: jennifer.st-pierre@wur.nl
1956). Within the rumen exist a group of La producers and a second group of La utilizers that ferment La to VFA (Dunlop and Hammond, 1965; Owens et al., 1998), the balance of which generally keeps the concentration of La in the rumen low. Accumulation of rumen La for animals fed large quantities of rapidly degradable starch or soluble sugars occurs when the rate of La production exceeds the capacity of the La-utilizing microbes for uptake. Nocek (1997) and Nagaraja and Titgemeyer (2007) speculated that as the concentration of La increases, rumen $\mathrm{pH}$ decreases, and lactic acidosis results. This further encourages the growth of acid-tolerant La-producing bacteria while inhibiting the growth of La utilizers, and results in a spiraling reduction of $\mathrm{pH}$ and elevating La concentration. Strategies to increase La utilizers or reduce La producers, or both, may be helpful in the prevention of acidosis. For example, feeding Megasphaera elsdenii, a major La utilizer, to beef cattle reduced rumen La concentration and increased $\mathrm{pH}$ (Calsamiglia et al., 2012).

High-yielding dairy cows fed energy-dense rations rich in rapidly fermentable starch or sugars are particularly susceptible to acidosis (Beauchemin and Penner, 2009), although feedlot beef cattle, sheep, goats and other ruminants are also prone to the disease (Braun et al., 1992). Rumen acidosis can be caused by improper adaptation to high-concentrate diets and the resulting accumulation of $\mathrm{La}$ in the rumen (acute acidosis; Nagaraja and Titgemeyer, 2007), or it can be caused by an accumulation of VFA within the rumen (subclinical acidosis; Oetzel et al., 1999; Beauchemin and Penner, 2009), both of which reduce rumen $\mathrm{pH}$. In dairy and beef cattle, clinical and subclinical acidosis are causes of substantial production loss as animals reduce feed intake or become susceptible to associated physiological complications such as laminitis, reduced fiber digestion, milk fat depression, diarrhea, and liver abscesses (Plaizier et al., 2008). Current feed evaluation systems for dairy cows (e.g., NRC, 2001; Thomas, 2004) are unable to address the complex interrelationships in the rumen that give rise to lactic acidosis following the ingestion 
of certain feedstuffs or combinations of feedstuffs. In more recent approaches, empirical relationships were developed assessing fiber requirements to avoid low rumen pH (Zebeli et al., 2008). Adequate fiber levels were predicted to depend on both level of DMI and dietary content of rumen degradable starch from grain, but this approach still does not include levels of rapidly degradable sugars or degradation characteristics of fiber. A mechanistic approach to feed evaluation demonstrates a greater capacity for describing such rumen fermentation processes, although to date, these models have given only minimal consideration to ruminal La metabolism (Dijkstra et al. 1992; Baldwin, 1995; Danfær et al., 2006). Therefore, the objective of this investigation was to develop a model of La metabolism and integrate it into an existing mechanistic model of whole-rumen function. The model could be used as a method of feed evaluation that accounts for the potential risk of lactic acidosis in the dairy cow adapted to a particular diet.

\section{MATERIALS AND METHODS}

\section{Model Development}

Existing models of rumen fermentation have tended to ignore the explicit description of La metabolism (Black et al. 1981; France et al. 1982; Dijkstra et al. 1992; Baldwin, 1995; Danfær et al., 2006). Where attempts have been made to account for La production and utilization, the approach taken has revolved around the manipulation of fermentation stoichiometry depending on rumen $\mathrm{pH}$ and fermentation substrate (Baldwin, 1995; Pitt et al. 1996). However, this technique is limited in its ability to describe reality, as several other factors associated with the fluctuations in the structure of the microbial population affect the potential for lactic acidosis. Rudimentary attempts at mechanistic modeling of La metabolism have since been made (Xu and Ding, 2006; Ding and $\mathrm{Xu}, 2006$ ), but require a more advanced representation of underlying fermentation and metabolism. The requirement for a more detailed description of the microbial population structure is a prerequisite for a model capable of quantifying La metabolism. Dijkstra (1994) modified an existing mechanistic model of rumen function (Dijkstra et al., 1992) to consider protozoal metabolism in conjunction with both amylolytic (Ba) and fibrolytic (Bc) bacteria populations. However, La was not represented as a state variable and dietary La entered the amylolytic hexose pool directly. The objectives of the Dijkstra (1994) model make it suitable for modification to account for rumen La metabolism, especially because protozoa (Po) may have a considerable role in the production and utilization of rumen La (Nagaraja and Towne, 1990; Williams and Coleman, 1997). Therefore, the model described herein, introduced previously by Dijkstra et al. (2002), is a modified form of the dynamic, deterministic rumen model presented by Dijkstra (1994). Within the Dijkstra (1994) model, $\mathrm{pH}$ is determined from both VFA and La concentration. Thus, although VFA are not explicitly dealt with in the current modeling exercise, large amounts of VFA, without significant amounts of La, may also decrease $\mathrm{pH}$ and cause acidosis within the model. The principal nutrient flows herein are as described by Dijkstra (1994) with key additional elements shown in Figure 1. The additional state variables and modifications to the existing driving and state variables are described below. Notation used to describe nutrient flows is shown in Table 1.

\section{Model Parameterization}

Unless otherwise indicated, the rumen model is parameterized according to Dijkstra (1994). Parameters for the La metabolism module are displayed in Tables 2 and 3. To the extent possible, diet-specific input values were obtained from the published experiments used in model evaluation. For the description of in situ degradation kinetics of feed carbohydrate and protein, the data presented by Nocek and Grant (1987), Tamminga et al. (1990), Van Vuuren et al. (1990), Nocek and Tamminga (1991), and Bosch et al. (1992) were used.

Pulsed Dietary Inputs. The original rumen model was evaluated with regard to its ability to run with a continuous input of nutrients, therefore simulating rumen fermentation in a frequently fed cow. Although the simulation of a steady state within the rumen during continuous feeding has proved effective for the simulation of many aspects of rumen fermentation, the objectives of this investigation require pulsed model inputs, thus simulating rumen function in the cow fed a limited number of meals during the day. France et al. (1982), Baldwin, (1995), and Chilibroste et al. (2001, 2008) describe models of whole-rumen function for which inputs were either continuous or pulsed to represent discontinuous feeding schedules. Due to the objectives of the present model, the approach taken by France et al. (1982) is used to simulate discontinuous feeding where instantaneous values for nutrient inputs $\left(D_{x}\right)$ are represented as follows:

$$
D_{x}=\frac{x}{n_{f} \Delta_{f}} \sum_{i=1}^{n_{f}}\left[H\left(t^{*}-t_{i}^{*}\right)-H\left(t^{*}-t_{i}^{*}-\Delta_{f}\right)\right],
$$

where $x$ is the nutrient intake $(\mathrm{kg} / \mathrm{d})$ ingested over $n_{f}$ equal meals, $t^{*}$ is the fractional part of the time variable $t(\mathrm{~d})$, and $\Delta_{f}$ is the duration of each meal. Feeding begins at time of day $t_{i}^{*}\left(i=1,2, \ldots, n_{f}\right)$ and 
Table 1. General notation used in the model

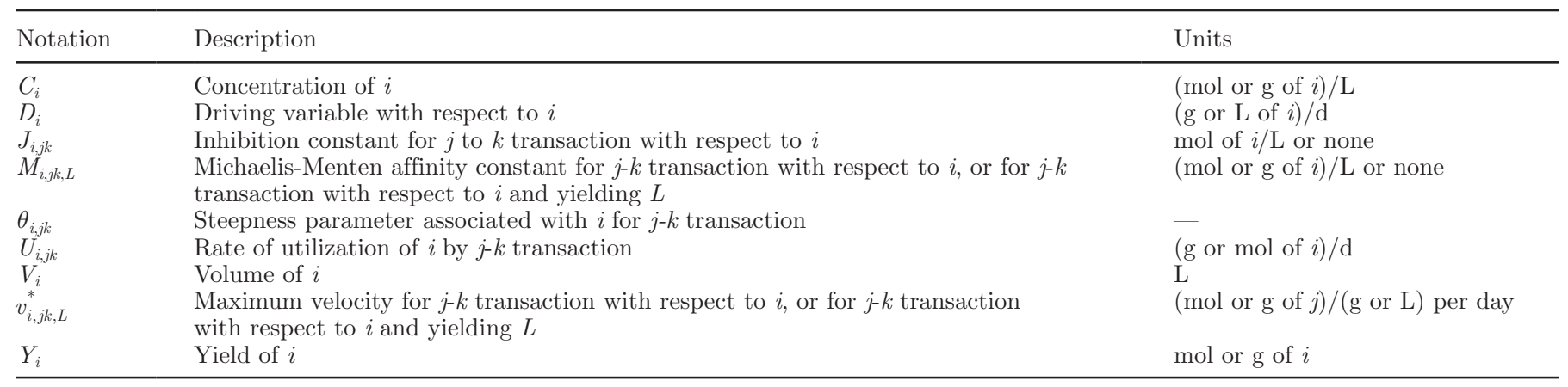

$H\left(t^{*}-t_{i}^{*}\right)=$ the step function $=0, t^{*}<h ;=1, t^{*} \geq h$.

A pulse function for feeding, $P_{f}(t)$ (per day), is therefore

$$
P_{f}(t)=\frac{1}{n_{f} \Delta_{f}} \sum_{i=1}^{n_{f}}\left[H\left(t^{*}-t_{i}^{*}\right)-H\left(t^{*}-t_{i}^{*}-\Delta_{f}\right)\right] .
$$

The dietary input functions are pulsed by multiplying the daily input constants by $P_{f}(t)$. Saliva flow is also pulsed with flow during feeding and ruminating being twice that during resting (France et al., 1982).
Rumination is assumed to occur following feeding and is equal in duration to the time spent eating. Total saliva flow is calculated from the DMI and NDF intake (Dijkstra, 1994).

Microbial Pools-General Considerations. Following ingestion of large amounts of rapidly available carbohydrate, La can accumulate in the rumen as the capacity of the La-producing bacteria to produce La exceeds utilization by the La-utilizing bacteria and Po. Dijkstra (1994) describes 3 microbial pools representing the $\mathrm{Po}$, the $\mathrm{Bc}$, and the $\mathrm{Ba}$. Therefore, within the present model, the $\mathrm{Ba}$ have been split into 2 separate

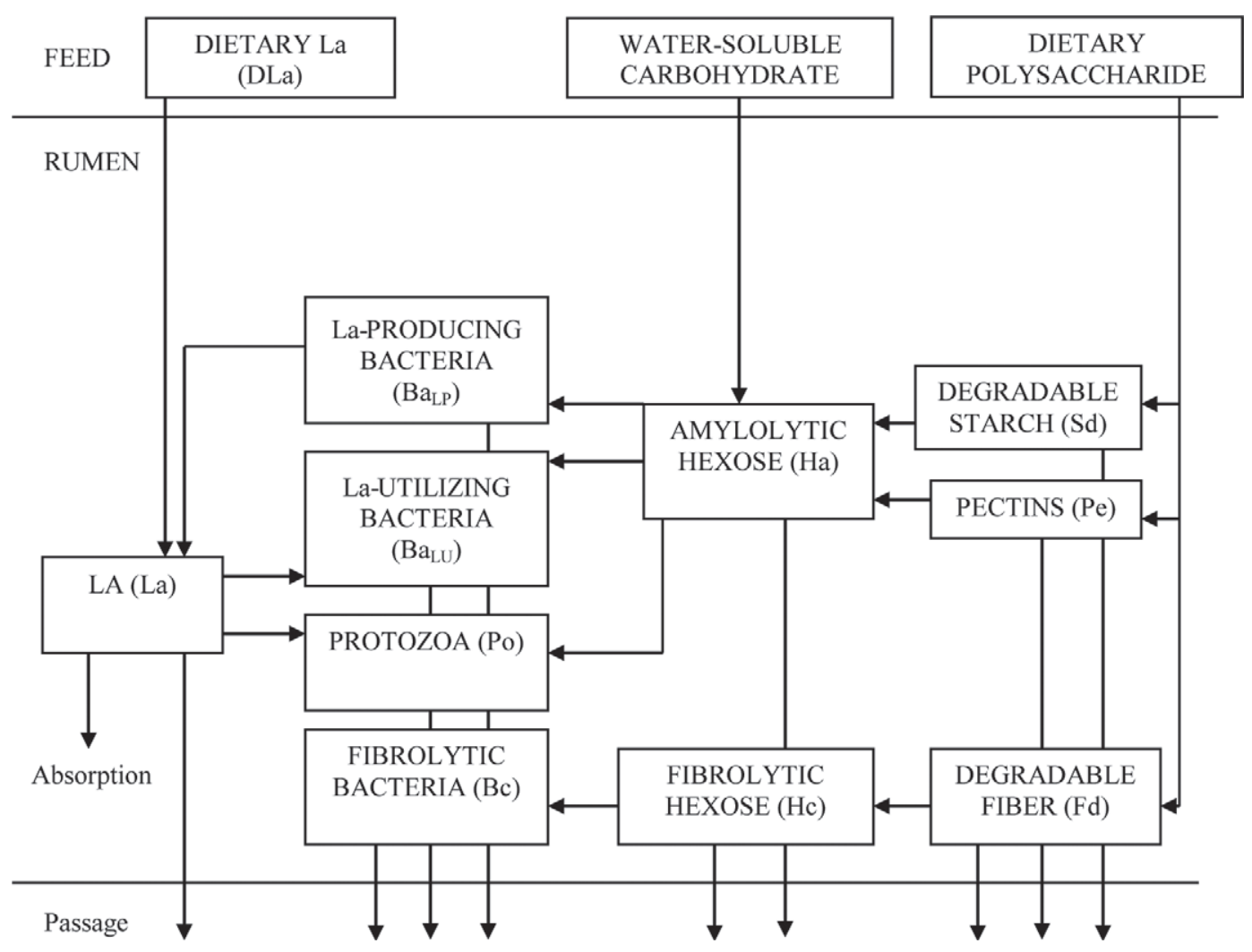

Figure 1. Diagrammatic representation of microbial groups and their energy substrates within the rumen model. La $=$ lactic acid. 
Table 2. Parameter values for microbial substrate uptake and lactic acid (La) absorption ${ }^{1,2}$

\begin{tabular}{|c|c|c|c|c|c|c|c|}
\hline Transaction & $M_{i, j k}$ & $v_{j k}^{*}$ or $v_{H a, j k}^{*}$ & $v_{L a, j k}^{*}$ or $v_{H a, j k, L a}^{*}$ & $M_{H a, j k}$ & $M_{L a, j k}$ & $J_{\mathrm{pH}, j k}$ & $\theta_{\mathrm{pH}, j k}$ \\
\hline $\mathrm{Am}, \mathrm{AmBa}_{\mathrm{LP}}$ & 0.00135 & 0.1720 & - & 0.0900 & - & - & - \\
\hline $\mathrm{Am}, \mathrm{AmBa} \mathrm{a}_{\mathrm{LU}}$ & 0.00135 & 0.0528 & 0.0848 & 0.0159 & 0.0010 & - & - \\
\hline $\mathrm{Ha}, \mathrm{HaSa}, \mathrm{Ba}_{\mathrm{LP}}$ & 0.1500 & 0.1750 & 0.2420 & - & - & - & - \\
\hline $\mathrm{Ha}, \mathrm{HaSa}, \mathrm{Ba}_{\mathrm{LU}}$ & 0.0268 & 0.0530 & - & - & - & - & - \\
\hline $\mathrm{Ha}, \mathrm{HaVa}, \mathrm{Ba}_{\mathrm{LP}}$ & 0.0045 & 0.1646 & 0.3700 & - & - & - & - \\
\hline $\mathrm{Ha}, \mathrm{HaVa}, \mathrm{Ba}_{\mathrm{LU}}$ & 0.0045 & 0.1646 & 0.7410 & - & - & - & - \\
\hline $\mathrm{La}, \mathrm{LaAb}$ & 0.0100 & - & 0.0008 & - & - & 3.5 & 2.0 \\
\hline La,LaPo & 0.0040 & - & 0.1680 & - & - & - & - \\
\hline La,LaSa & 0.0017 & - & 0.2420 & - & - & - & - \\
\hline La,LaSp & 0.0080 & - & 0.0490 & - & - & - & - \\
\hline $\mathrm{La}, \mathrm{LaVa}$ & 0.00028 & - & 0.7410 & - & - & - & - \\
\hline $\mathrm{P}_{\mathrm{s}}, \mathrm{PsBa}_{\mathrm{LP}}$ & 0.0224 & 0.1850 & - & 0.1400 & - & - & - \\
\hline $\mathrm{Ps}_{\mathrm{s}}, \mathrm{PsBa}_{\mathrm{LU}}$ & 0.0224 & 0.0576 & 0.0931 & 0.0248 & 0.0016 & - & - \\
\hline
\end{tabular}

${ }^{1}$ See Table 1 for explanation of notation.

${ }^{2} \mathrm{Am}=$ ammonia $; \mathrm{Ba}_{\mathrm{LP}}=$ La-producing bacteria; $\mathrm{Ba}_{\mathrm{LU}}=$ La-utilizing bacteria Ha = amylolytic hexose; $\mathrm{Sa}=$ amylolytic storage polysaccharide; $\mathrm{Ab}=$ absorption; $\mathrm{Po}=$ protozoa; $\mathrm{Sp}=$ protozoal storage polysaccharide; $\mathrm{Ps}=$ soluble protein; $\mathrm{Va}=\mathrm{VFA}$.

populations comprising the La producers $\left(\mathbf{B a}_{\mathbf{L P}}\right)$ and the La utilizers $\left(\mathbf{B a}_{\mathbf{L U}}\right)$. The polysaccharide free DM of the bacterial groups is assumed equal as described in Dijkstra (1994). The fraction of hexose incorporated or fermented for energy by the rumen microbes is taken from Table 3 of Dijkstra (1994), and on the basis that, $1 \mathrm{~mol}$ of hexose fermented to La yields $2 \mathrm{~mol}$ of ATP. The fraction of La incorporated or fermented is calculated assuming that $1 \mathrm{~mol}$ of La fermented produces 1 mol of ATP. The Ba $a_{\mathrm{LU}}$ are able to utilize both La and amylolytic hexose as energy sources. Therefore, $\mathrm{Ba}_{\mathrm{LU}}$ also represent those bacteria neither producing nor utilizing La. Protozoa also have the ability to utilize either hexose or La for maintenance and growth (Williams and Coleman, 1997). Fibrolytic bacteria remain unchanged from the representation of Dijkstra (1994).

To reflect the ability of $\mathrm{Ba}_{\mathrm{LU}}$ and Po to utilize either La or hexose as an energy substrate, a similar transaction is present for La wherever hexose metabolism occurs involving these 2 microbial groups. Hexose metabolism is as presented by Dijkstra (1994) for Ba and Po. Therefore, only specific differences in the nature of the flows are presented here along with the parameter values applied for La metabolism. Through increasing the level of competition for amylolytic hexose, following the introduction of different bacterial groups, situations may exist where certain bacterial pools disappear within the model. Disappearance of amylolytic microbes could occur with high-fiber diets low in amylolytic hexose availability or where long periods of fasting are simulated. Disappearance of Bc could occur with lowfiber diets or when low rumen $\mathrm{pH}$ is simulated. In reality, microbial adherence to the rumen epithelium, and dynamic changes and fluctuations in $\mathrm{pH}$ throughout the day, spatially within the rumen as well as through cross-feeding of cellodextrins, prevent such major sim- plifications of microbial population structure (Dijkstra et al., 2012), and some of the minimized microbial pool will remain (e.g., Leedle et al., 1982). Therefore, for this exercise, minima were set so that no amylolytic microbial group was allowed to decline to less than $2 \%$ of the total Ba population. This assumption is critical because if a particular microbial population is allowed to decline to zero, the model may become unstable. In reality, the spatial distribution of microbes and digesta within the rumen and the constant inoculation through feeding activity prevent such drastic population declines. However, the most straightforward way to mimic

Table 3. Fermentation and protozoal uptake parameter values

\begin{tabular}{lc}
\hline Parameter $^{1}$ & Value \\
\hline$Y L a_{\max }$ & 1.0 \\
$Y L a_{\min }$ & 0.035 \\
$\theta_{\mathrm{pH} Y L a}$ & 33.0 \\
$M_{\mathrm{pH} Y L a_{\min }}$ & 4.87 \\
$M_{\mathrm{pH} Y L a_{\max }}$ & 7.0 \\
$M_{G r Y L a}$ & 10.8 \\
$v c_{G r Y L a}$ & 4.8 \\
$J_{P x P o}$ & 5.5 \\
$M_{P x P o}$ & 1.75 \\
$\Delta_{\mathrm{pH}}$ & 6.0 \\
$\theta_{P x P o 1}$ & 40.0 \\
$\theta_{P x P o 2}$ & 2.5 \\
\hline
\end{tabular}

${ }^{1} Y L a_{\max }=$ maximum value of the proportion of hexose fermented to lactic acid $(Y L a) ; Y L a_{\min }=$ minimum value of $Y L a ; \theta_{\mathrm{pH} Y L a}=$ equation steepness parameter; $M_{\mathrm{pH} Y L a_{\min }}$ and $M_{\mathrm{pH} Y L a_{\max }}=$ minimum and maximum rumen $\mathrm{pH}$ between which $M_{\mathrm{pH} Y L a}$ varies according to the specific growth rate; $M_{G r Y L a}=$ the specific growth rate; $v c_{G r Y L a}=$ critical specific growth rate below which $M_{\mathrm{pH} Y L a}$ equals $M_{\mathrm{pH} Y L a_{\min }} ; J_{P x P o}=$ the $\mathrm{pH}$ above $\Delta \mathrm{pH}$ where protein uptake is half maximal minus $\Delta \mathrm{pH} ; M_{P x P o}$ $=$ the $\mathrm{pH}$ between which $\Delta \mathrm{pH}$ and zero at which engulfment is half maximal; $\Delta \mathrm{pH}=$ the $\mathrm{pH}$ for maximum protein uptake by protozoa; $\theta_{P x P o 1}$ and $\theta_{P x P o 2}=$ equation steepness parameters. 
this in the model is to adopt a minimum level for each microbial group.

$\boldsymbol{B} \boldsymbol{a}_{L P}$. It is likely that a core microbiome exists within the rumen that is generally responsible for La production (Jami and Mizrahi, 2012). Within this group, Streptococcus bovis is a major contributor (Nagaraja and Titgemeyer, 2007), with lactobacilli proliferating only in the most acidic conditions (Stewart, 1992). In the absence of specific growth data for this complex in vivo group of microbes, the metabolism of $\mathrm{Ba}_{\mathrm{LP}}$ is taken to resemble that of Strep. bovis, where published data are available for parameterization. The La-producing bacteria ferment amylolytic hexose as their sole source of energy. However, they metabolize a varying proportion of fermented hexose to either La or VFA, depending on specific growth rate (Russell and Baldwin, 1979a) and rumen $\mathrm{pH}$ (Russell and Dombrowski, 1980). When $\mathrm{pH}$ was held between 6.60 and 6.85 , an increase in growth rate from 0.082 to $2.04\left(\mathrm{~h}^{-1}\right)$ produced large variations in the ratio of La produced to glucose metabolized by Strep. bovis in continuous culture (Russell and Baldwin, 1979a). Therefore, the proportion of hexose fermented to La of total glucose fermentation by $\mathrm{Ba}_{\mathrm{LP}}$ is assumed to increase as specific growth rate increases and as $\mathrm{pH}$ declines as follows:

$$
Y L a(L a: H a)=Y L a_{\min }+\frac{\left(Y L a_{\max }-Y L a_{\min }\right)}{\left[1+\left(\mathrm{pH} / M_{\mathrm{pH} Y L a}\right)^{\theta_{\mathrm{pH} Y L a}}\right]},[3]
$$

where $Y L a$ is the proportion of hexose fermented to La; $H a$ is amylolytic hexose; $Y L a_{\max }$ is the maximum value of $Y L a ; Y L a_{\min }$ is the minimum value of $Y L a ; M_{\mathrm{pH} Y L a}$ is the $\mathrm{pH}$ of the rumen fluid when $Y L a$ is half maximal; and $\theta_{\mathrm{pHYLa}}$ is a steepness parameter (mathematical notation and units are summarized in Table 1). These parameters were calculated by fitting Equation 3 to the in vitro data of Russell and Baldwin, (1979a). The $M_{\mathrm{pH} Y L a}$ value varies with specific growth rate of LP according to

$$
\begin{aligned}
& M_{\mathrm{pH} Y L a}(\mathrm{pH})=M_{\mathrm{pH} Y L a_{\min }}+ \\
& \frac{\left(M_{\mathrm{pH} Y L a_{\max }}-M_{\mathrm{pH} Y L a_{\min }}\right)}{1+\left[2 M_{G r Y L a} /\left(v_{G r Y L a}-v c_{G r Y L a}+\left|v_{G r Y L a}-v c_{G r Y L a}\right|\right)\right]},
\end{aligned}
$$

where $M_{\mathrm{pH} Y L a_{\min }}$ and $M_{\mathrm{pH} Y L a_{\max }}$ are the minimum and maximum $\mathrm{pH}$ between which $M_{\mathrm{pH} Y L a}$ varies according to the specific growth rate; $v_{G r Y L a}$ and $v c_{G r Y L a}$ are the specific growth rate and the critical specific growth rate below which $M_{\mathrm{pH} Y L a}$ equals $M_{\mathrm{pH} Y L a_{\min }}$ of the $\mathrm{Ba}_{\mathrm{LP}}$, re- spectively; $\left|v_{G r Y L a}-v c_{G r Y L a}\right|$ represents the absolute value of the specific growth rate minus the critical specific growth rate; and $M_{G r Y L a}$ is the specific growth rate where $Y L a$ is half maximal. Parameter estimates for Equation 4 were calculated by fitting the data of Russell and Dombrowski (1980) to Equation 4 using PROC GLM of SAS (SAS Institute, 2000).

A principal physiological characteristic of La-producing bacteria in the rumen is the rapid growth rate under conditions of high substrate availability. Russell and Baldwin (1979b) estimated a maximum specific growth rate for Strep. bovis in vitro of $20 / \mathrm{h}$, although they cast doubt on the reliability of such a high figure due to problems with the culture technique. More conservative estimates were obtained by Russell et al. $(1979 ; 1.85 / \mathrm{h})$ and by Russell and Baldwin (1979a; 2.04/h). Therefore, $\mathrm{Ba}_{\mathrm{LP}}$ were parameterized according to a maximum specific growth rate of $0.85 / \mathrm{h}$ on ammonia and $1.15 / \mathrm{h}$ on soluble protein, yielding a combined maximum growth rate of $2.0 / \mathrm{h}$. The differential in growth rate on ammonia and protein is estimated by adopting the same ratio as used by Dijkstra (1994) for Ba. Maximum velocities of ammonia $\left(v_{A m, A m \mathrm{Ba}_{\mathrm{LP}}}^{*}\right)$ and soluble protein $\left(v_{P s, P s \mathrm{Ba}_{\mathrm{LP}}}^{*}\right)$ uptake by $\mathrm{Ba}_{\mathrm{LP}}$ were calculated from the maximum specific growth rates on the respective substrates and the requirements for ammonia and soluble protein taken from Dijkstra (1994). Maximum uptake rate of hexose for storage polysaccharide $\left(v_{\mathrm{Ha}, \mathrm{HaSa}, \mathrm{Ba}_{\mathrm{LP}}}^{*}\right)$ was calculated assuming a maximum storage polysaccharide content of $0.29 \mathrm{~g}$ per gram of bacteria and hexose requirements from Dijkstra (1994). Maintenance energy requirements of $\mathrm{Ba}_{\mathrm{LP}}$ are discussed in the next section in relation to La-utilizing bacteria.

Affinity constants for ammonia and soluble protein were equal to those for Ba in Dijkstra (1994). Hexose affinity constants for growth on ammonia $\left(M_{H a, A m \mathrm{Ba}_{\mathrm{LP}}}\right)$ and soluble protein $\left(M_{H a, P s \mathrm{Ba}_{\mathrm{LP}}}\right)$ were based on the in vitro data from Russell and Baldwin (1979b), assuming that $\mathrm{Ba}_{\mathrm{LP}}$ have an affinity 6 times lower than $\mathrm{Ba}_{\mathrm{LU}}$ during competition for hexose. This assumption means that $\mathrm{Ba}_{\mathrm{LU}}$ are more effective competitors at low hexose concentrations but that $\mathrm{Ba}_{\mathrm{LP}}$ are able to grow relatively faster when hexose concentrations rise significantly. Hexose affinity for storage polysaccharide $\left(M_{\mathrm{Ha}, \mathrm{HaSa}, \mathrm{Ba}_{\mathrm{LP}}}\right)$ was calculated assuming that the ratio between $M_{H a, A m \mathrm{Ba}_{\mathrm{LP}}}$ and $M_{\mathrm{Ha}, \mathrm{HaSa}, \mathrm{Ba} \mathrm{LP}_{\mathrm{LP}}}$ was similar to that for $\mathrm{Ba}$ in Dijkstra (1994).

$\boldsymbol{B} \boldsymbol{a}_{L U}$. The La-utilizing bacteria can utilize either hexose or La as substrates for maintenance and growth. This composite bacterial group represents mixed $\mathrm{Ba}$ during normal fermentation conditions. When rumen 
La concentration increases relative to hexose, the characteristics of $\mathrm{Ba}_{\mathrm{LU}}$ shift toward those associated with La-utilizing bacteria. Although the overall presence of the microbe group in the rumen may be low or contingent on diet (Stewart et al., 1997; Ouwerkerk et al., 2002; Klieve et al. 2003), Counotte et al. (1981) showed that Megasphaera elsdenii accounted for the majority (60-85\%) of La fermentation in the rumen. In the absence of published growth parameters for a broader range of La-utilizing bacteria, La fermentation parameters for this group are based on those reported for $M$. elsdenii. Fermentation parameters for hexose are identical to those described for Ba by Dijkstra (1994). Maximum rates of ammonia $\left(v_{A m L a, A m B \mathrm{Ba}_{\mathrm{LU}}}^{*}\right)$ and soluble protein $\left(v_{P s L a, P s \mathrm{Ba}_{\mathrm{LU}}}^{*}\right)$ uptake are calculated assuming a maximum specific growth rate during growth on La of $0.42 / \mathrm{h}$ with ammonia and $0.58 / \mathrm{h}$ with protein. This yields a combined maximum specific growth rate of $1.0 / \mathrm{h}$ and is identical to that reported by Russell and Baldwin (1979b) for M. elsdenii grown on La. This is $60 \%$ higher than the maximum specific growth rate for $\mathrm{Ba}_{\mathrm{LU}}$ on hexose presented by Dijkstra (1994) for Ba. Therefore, $\mathrm{Ba}_{\mathrm{LU}}$ have the opportunity to grow faster when $M$. elsdenii predominate under conditions of high La availability, representing the change in microbial structure following the feeding of substantial quantities of degradable carbohydrate and the resulting competition with Strep. bovis (Ba $\mathrm{LP}_{\mathrm{LP}}$; Russell et al., 1981). Maximum rate of La uptake for storage polysaccharide $\left(v_{\text {La,LaSa }}^{*}\right)$ was calculated as for hexose uptake for storage polysaccharide.

Affinity constants for ammonia and soluble protein are unchanged from Dijkstra (1994). Hexose affinity constants also remain similar to previously published values, allowing $\mathrm{Ba}_{\mathrm{LU}}$ to represent mixed $\mathrm{Ba}$ during growth on hexose. Affinity for $\mathrm{La}\left(M_{L a, A m \mathrm{Ba}_{\mathrm{LU}}}, M_{L a, P s \mathrm{Ba}}\right)$ is set relative to typical basal La concentration $(1.0 \times$ $10^{-4}$ to $2.0 \times 10^{-4} \mathrm{~mol} / \mathrm{L}$ ) and the comparative affinity of $\mathrm{Ba}_{\mathrm{LU}}$ for hexose, assuming a basal hexose concentration of $0.002 \mathrm{~mol} / \mathrm{L}$. Therefore, changes in the relative La and hexose concentrations bring about the appropriate shift in energy substrate utilization. The affinity for La uptake for storage polysaccharide by $\mathrm{Ba}_{\mathrm{LU}}$ $\left(M_{L a, L a S a}\right)$ is set relative to uptake affinity for growth on ammonia by applying the same differential as between the hexose parameters for the equivalent transactions.

Instead of an explicit maintenance requirement for rumen bacteria, Dijkstra et al. (1992) introduced the concept of a variable energy requirement for functions not related to growth that was dependent on the availability of ammonia and soluble protein. This representation has been maintained in the present model. Clear differences exist in the calculated maximum hexose catabolism rates between the $2 \mathrm{Ba}$ groups when applying the maximum specific growth rates previously described. Therefore, one might expect $v_{\mathrm{Ha}, \mathrm{HaVa}, \mathrm{Ba}_{\mathrm{LU}}}^{*}$ to be higher than $v_{H a, H a V a, \mathrm{Ba}_{\mathrm{IP}}}^{*}$, where $\mathrm{Va}$ are VFA. However, Russell and Baldwin (1979a) and Russell et al. (1981) observed maintenance energy expenditures for Strep. bovis that were marginally lower than for $M$. elsdenii. Even over a range of $\mathrm{pH}$ from 5.7 to 6.6 , Russell et al. (1981) did not observe a difference in the relative maintenance requirements between the 2 species. These data suggest that the differences in maintenance energy expenditure are small and unlikely to influence the competition between $\mathrm{Ba}_{\mathrm{LP}}$ and $\mathrm{Ba}_{\mathrm{LU}}$. For this reason, the hexose utilization parameters for non-growth purposes presented by Dijkstra (1994) were adopted for both $\mathrm{Ba}_{\mathrm{LP}}$ and $\mathrm{Ba}_{\mathrm{LU}}$. For La production by $\mathrm{Ba}_{\mathrm{LP}}$ or La utilization by $\mathrm{Ba}_{\mathrm{LU}}, v_{\mathrm{La}, \mathrm{HaVa} a}^{*}$ and $v_{\mathrm{Ha}, \mathrm{HaVa}, \mathrm{La}}^{*}$ were corrected for ATP yield as described in the Microbial PoolsGeneral Considerations section above.

Po. A protozoal pool was explicitly represented in the model of Dijkstra (1994). However, in recognition of the significance of La as a substrate for protozoal metabolism, this pool was modified to allow growth on both hexose and La.

In the absence of published data regarding protozoal growth yields on La, the cell yield on La is taken to be the same as for growth on hexose. Therefore, the maximum La uptake rate by $\mathrm{Po}\left(v_{L a, L a P o}\right)$ is set at 0.168 $\mathrm{mol} / \mathrm{g}$ of Po per day. This is in broad agreement with Chamberlain et al. (1983) who observed an La uptake of $0.125 \mathrm{~mol} / \mathrm{g}$ of Po per day for rumen Po in vitro and Newbold et al. (1987) who showed La disappearance rates ranging from 0.025 to $0.206 \mathrm{~mol} / \mathrm{g}$ of Po per day, depending on diet.

Within the original model, the growth of the protozoal population was not affected directly by rumen $\mathrm{pH}$. However, protozoal engulfment of bacteria has been shown to be $\mathrm{pH}$ sensitive, with an optimum at $\mathrm{pH} 6.0$, declining to zero at $\mathrm{pH} 5.0$, and $75 \%$ at $\mathrm{pH} 7.0$ and $30 \%$ at pH 8.0 (Coleman and Sandford, 1979). Therefore, given the objectives of the current model, the maximum uptake of bacterial protein and feed protein depends on $\mathrm{pH}\left(v_{P o, P x P o_{\text {corr }}}\right)$ and is calculated as follows:

$$
v_{P o, P x P o_{c o r r}}=\frac{1}{\left[1+\left(\frac{M_{P x P o}}{\mathrm{pH}}\right)^{\theta_{P x P o 1}}\right]} \times \frac{1}{\left[1+\left(\frac{\Delta_{\mathrm{pH}}+\mid \Delta_{\mathrm{pH}}}{2 J_{P x P o}}\right)^{\theta_{P x P o 2}}\right]},
$$

where $\Delta_{\mathrm{pH}}$ is the $\mathrm{pH}$ for maximum protein uptake by Po, $M_{P x P o}$ is the $\mathrm{pH}$ between $\Delta_{\mathrm{pH}}$ and zero at which 
engulfment is half maximal, $J_{P x P o}$ is the $\mathrm{pH}$ above $\Delta_{\mathrm{pH}}$ where protein uptake is half maximal minus $\Delta_{\mathrm{pH}}$, and $\theta_{P x P o 1}$ and $\theta_{P x P o 2}$ are steepness parameters. All parameters were estimated by fitting the data of Coleman and Sandford (1979) to Equation 5 using PROC GLM of SAS.

Published estimates of protozoal affinity for La uptake are not available. Therefore, $M_{L a, L a P o}$ is set arbitrarily at 30 times basal La concentration $(1.0 \times$ $10^{-4}$ to $\left.2.0 \times 10^{-4} \mathrm{~mol} / \mathrm{L}\right)$ in view of the preference of Po for hexose (Williams and Coleman, 1997) unless La concentrations are high and the entodiniomorphid Po predominate. The vestibuliferids show virtually no capacity for La uptake (Newbold et al., 1987; Ellis et al., 1991). The affinity for La uptake for storage polysaccharide $M_{L a, L a S p}$ is set relative to $M_{L a, L a P_{o}}$ using the ratio between hexose uptake for storage polysaccharide and hexose uptake for maintenance and growth defined by Dijkstra (1994).

$\boldsymbol{L a}$. Inputs to the La pool are directly from the feed and from fermentation of hexose by $\mathrm{Ba}_{\mathrm{LP}}$ during growth on soluble protein or ammonia or for non-growth purposes. Outputs from this pool are from passage with the rumen fluid, absorption through the rumen wall, uptake for growth with soluble protein or ammonia by the $\mathrm{Ba}_{\mathrm{LU}}$, uptake for non-growth purposes by $\mathrm{Ba}_{\mathrm{LU}}$, and uptake for protozoal maintenance and growth.

As with VFA, the absorption of La across the rumen wall is via passive diffusion and increases as rumen $\mathrm{pH}$ declines. However, the rate of La absorption from the rumen is much slower than that of VFA (Møller et al., 1997). Despite passive diffusion across the rumen epithelium, saturation kinetics are used to account for La accumulation within the receiving cell, especially at relatively high rates of absorption. Hence, La absorption $\left(U_{L a, L a A b}\right)$ is described as follows:

$$
U_{L a, L a A b}=\frac{v_{L a, L a A b} S A_{R u}}{\left(1+M_{L a, L a A b} / C_{L a}\right) /\left[1+\left(\mathrm{pH} / J_{\mathrm{pH}, L a A b}\right)^{\theta_{\mathrm{pH}, L a A b}}\right]},
$$

where $v_{L a, L a A b}$ is the maximum rate of absorption from the rumen; $M_{L a, L a A b}$ and $J_{\mathrm{pH}, L a A b}$ are the concentration of rumen $\mathrm{La}$ and $\mathrm{pH}$, respectively, when La absorption is half maximal; $C_{L a}$ is the concentration of La; and $\theta_{\mathrm{pH}, L a A b}$ is a steepness parameter. These parameters were calculated from the in vivo data of Williams and Mackenzie (1965) and the in vitro results from Møller et al. (1997). The parameter $S A_{R u}\left(\mathrm{~cm}^{2}\right)$ is the absorptive surface area of the rumen and is determined assuming that the rumen is a sphere and is half full:

$$
S A_{R u}=2 \pi\left(\sqrt[3]{3 V_{R u} / 2 \pi}\right)^{2},
$$

where $V_{R u}\left(\mathrm{~cm}^{3}\right)$ is the volume of the rumen contents.

Fermentation of La to VFA is calculated using a constant stoichiometry taken from sheep in the radioisotope study of Gill et al. (1986). This approach ignores any change in fermentation stoichiometry due to rumen $\mathrm{pH}$ and passage rate (Counotte et al., 1981) or the different end products arising from the fermentation of D- and L-La isomers (Counotte et al., 1983). However, published data are confounded by the effects of La concentration on the stoichiometric balance (Gill et al., 1986) and, therefore, a fixed stoichiometry has been adopted. Where $1 \mathrm{~mol}$ of fermented La yields 0.95 mol of VFA (Baldwin, 1995), the stoichiometric coefficients are 0.571 acetate, 0.333 propionate, and 0.0487 butyrate.

The earlier rumen model (Dijkstra et al., 1992; Dijkstra, 1994) requires the mean rumen $\mathrm{pH}$ to be specified as an input, taken from experimental observations. In conjunction with the mean $\mathrm{pH}$ value, the minimum daily $\mathrm{pH}$ and time below a critical $\mathrm{pH}$ values $(\mathrm{pH} 6.3)$ were required, due to the influence of these parameters on absorptive processes, fiber degradation, and microbial recycling within the rumen. Bannink et al. (1997) described these $\mathrm{pH}$ values as uncertain inputs within the model and showed significant variation in duodenal NDF flow following a sensitivity analysis that involved manipulation of these parameters within acceptable limits. Indeed, the objectives of the present modeling exercise demand a dynamic rumen $\mathrm{pH}$ that fluctuates with the feeding cycle. Attempts to predict rumen $\mathrm{pH}$ from VFA concentration have shown some success (Briggs et al., 1957; Argyle, 1989), although this is still a simplification of the factors determining $\mathrm{pH}$ in the rumen (Dijkstra et al., 2012). Lactic acid [dissociation constant $(\mathrm{pK})=3.86]$ is a stronger acid than the VFA (pK $\sim 4.80)$ though, and an increase in concentration above typical basal levels of $2.0 \times 10^{-4}$ to $4.0 \times 10^{-4}$ $\mathrm{mol} / \mathrm{L}$ can cause a significant reduction in rumen $\mathrm{pH}$ (Harmon et al., 1985). Therefore, for simulations involving dairy cows here, rumen $\mathrm{pH}$ was calculated using the relationship described by Tamminga and Van Vuuren (1988), with a modification to include the depressing effect of La, where

$$
\mathrm{pH}=7.73-0.014 C_{\mathrm{VFA}}-0.0154 C_{\mathrm{La}},
$$

where $C_{\mathrm{VFA}}$ and $C_{\mathrm{La}}$ are the concentrations $(\mathrm{mmol} / \mathrm{L})$ of VFA and La in the rumen, respectively. For simulation of experiments using sheep, the relationship described 
by Argyle (1989) based on the observations of Briggs et al. (1957) are used.

\section{Model Summary}

The differential equations of the 21 state variables, representing the nutrient and microbial pools in the rumen, were integrated numerically for a given set of initial conditions and parameter values. The model was written in Advanced Continuous Simulation Language (ACSL; version 11; Aegis Technologies Group, Huntsville, AL). A fourth-order fixed-step-length Runge-Kutta method with an integration interval of $3.472 \times 10^{-4}$ $\mathrm{d}$ was used. The results presented were obtained by running the model until quasi-steady state was reached.

\section{Model Evaluation}

Sensitivity Analysis. The sensitivity of the model to changes in parameters related to La metabolism was investigated using 2 high-concentrate diets (20\% forage) and a predominantly grass silage (GS) diet $(80 \%$ forage). The 2 high-concentrate diets differed in carbohydrate source, one being high in rumen-degradable NSC (SC diet) and the other high in corn starch (M diet). Diets used for sensitivity analysis were fed at 20 $\mathrm{kg}$ of $\mathrm{DM} / \mathrm{d}$ in 2 equal meals $12 \mathrm{~h}$ apart. Each meal was 45 min in duration. Grass silage composition was (in g/ $\mathrm{kg}$ of DM) as follows: NDF, 580; starch and sugars, 40; nitrogen, 26; and La, 70. The concentrate for diet SC consisted of $40 \%$ barley starch, $30 \%$ cane molasses, $15 \%$ rapeseed meal, and 15\% soybean meal. The concentrate for the $\mathrm{M}$ diet was the same as for the SC diet, with barley and molasses being replaced by dry ground corn. Parameters selected for sensitivity analysis were those closely associated with La metabolism or amylolytic microbial competition. Selected parameters were set at $\pm 20 \%$ of model values to evaluate sensitivity (see Table 5), which is a substantial enough variation to detect overly sensitive model parameters.

Comparison of Predicted and Observed Data. The majority of studies reporting rumen La concentrations involve animals unadapted to the experimental diet. These studies are not suitable for model evaluation due to differences in the metabolism of rumen La between unadapted and adapted animals (Malestein et al., 1984). For example, experiments to determine the effects of feeding high levels of rapidly degradable carbohydrates on rumen La accumulation report large variations in rumen La concentrations. Hyldgaard-Jensen and Simesen (1966) observed a peak rumen La concentration of $0.337 \mathrm{~mol} / \mathrm{L}$ in cattle fed large quantities of cereal grain following a period of starvation, whereas Dunlop and Hammond (1965) reported a peak rumen
La concentration of $228 \mathrm{mmol} / \mathrm{L}$ for a steer engorged on ground maize. However, where animals were gradually adapted to a diet high in degradable carbohydrate, the postfeeding increase was less severe. Malestein et al. (1984) observed declining peak La concentrations over a 5 -d period for dairy cows fed $6 \mathrm{~kg}$ of concentrate. However, Malestein et al. (1984) also showed that this response was feedstuff dependent. Counotte et al. (1983) observed a peak La concentration of $0.029 \mathrm{~mol} / \mathrm{L}$ in the rumen of a dairy cow fed $6 \mathrm{~kg}$ of concentrate following a 75-d adaptation. Ghorban et al. (1966) demonstrated a range of peak La values depending on carbohydrate source from 0.0022 to $0.0083 \mathrm{~mol} / \mathrm{L}$ for nonlactating cattle.

Of those studies utilizing adapted animals, Counotte et al. (1983), Chamberlain et al. (1983), Newbold et al. (1986) and Mackie et al. (1984) provide enough dietary information for input into the rumen model. Newbold et al. (1986) conducted 2 experiments involving sheep either fed sugar beet pulp and barley (80:20; experiment 1 ) or barley and grass hay (60:40; experiment 2) infused with $\mathrm{Na}$ DL-lactate at doses from 0 to $100 \mathrm{~g} / \mathrm{d}$. In those trials, Newbold et al. (1986) examined the effects of defaunation on the metabolism of La. Therefore, the results of Newbold et al. (1986) facilitate evaluation of the model with regard to Po and dietary La metabolism. Mackie et al. (1984) used sheep to investigate the metabolism of La for high-concentrate, intermediate, high-roughage, and lucerne hay diets. Mackie et al. (1984) used DL- $\left[2{ }^{14}\right]$ La to measure La production and utilization rates in the rumen. Therefore, their data can be used to evaluate the ability of the model to simulate La production and utilization rather than net accumulation alone. Chamberlain et al. (1983) presented data for the accumulation of La in the rumen of 6 Ayrshire cows fed GS diets ( $67 \mathrm{~g}$ of La/ $\mathrm{kg}$ of DM), whereas Counotte et al. (1983) fed a 60\% concentrate (DM basis) diet to lactating Holstein dairy cows. Diet summaries for the evaluation studies are shown in Table 4.

Regression analysis between observed and predicted values for the evaluation studies was performed using mean square prediction error (MSPE) to demonstrate the reliability of model predictions, where MSPE is calculated as follows:

$$
\text { MSPE }=\sum_{i=1}^{n}\left(O_{i}-P_{i}\right)^{2} / n,
$$

where $n$ is the total number of observations, $O_{i}$ is the observed value, and $P_{i}$ is the predicted value. The square root of the MSPE (RMSPE), expressed as a percentage of the observed mean, gives an estimate of the overall prediction error. The RMSPE can be de- 
composed into error due to overall bias, error due to deviation of the regression slope from unity, and error due to the disturbance (random error; Bibby and Toutenburg, 1977).

\section{RESULTS AND DISCUSSION}

\section{Sensitivity Analysis}

The model responses with regard to La metabolism are shown in Table 5. As expected, the SC diet gave the highest peak rumen La concentration followed by the GS and M diets (Table 5). The relatively low level of rumen La for the M diet represents the comparatively low rate of degradation of corn starch. The peak in La concentration on the GS diet resulted entirely from dietary inputs rather than endogenous production. Minimum La concentrations were very low for all 3 diets compared with typical basal levels of $1.0 \times$ $10^{-4}$ to $2.0 \times 10^{-4} \mathrm{~mol} / \mathrm{L}$. It is likely that the level of La production during the mid-feeding cycle was underpredicted (see Comparison Between Observed and Predicted Results section). The mean contribution of $\mathrm{Ba}_{\mathrm{LU}}$ to La utilization varied from $71.7 \%$ for the $\mathrm{M}$ diet to $98.3 \%$ for the SC diet. This is the result of competition with Po for La. The contribution of $\mathrm{Ba}_{\mathrm{LU}}$ to total La utilization followed peak rumen La concentration, with higher contributions associated with the highest La concentrations. Simulated maximum protozoal contribution to La utilization was highly variable, ranging from 13.8 to $53.5 \%$.

An increase in the affinity of $\mathrm{Ba}_{\mathrm{LP}}$ for hexose $\left(M_{H a, A m B a}\right.$ and $M_{H a, P s B a}$, with 0.090 and $0.140 \mathrm{~mol} / \mathrm{L}$ as default values, respectively, derived in the $\mathrm{Ba}_{\mathrm{LP}}$ section) produced a substantial rise in peak rumen La concentration. The effect was greatest for the SC diet because amylolytic hexose concentration was least limiting for nitrogen uptake. Minimum La concentration remained very low across all diets and contributions to La utilization by $\mathrm{Ba}_{\mathrm{LP}}$ and Po were largely unaffected by changes in $M_{H a, A m B a_{\mathrm{LP}}}$ and $M_{H a, P s B a}$. The model was comparatively insensitive to the raising or lowering of affinity of $\mathrm{Ba}_{\mathrm{LU}}$ for La during growth $\left(M_{L a, A m \mathrm{Ba}_{\mathrm{LU}}}\right.$ and $M_{L a, P s B a}$, with 0.0010 and 0.0016 $\mathrm{mol} / \mathrm{L}$ as default values, respectively, derived in the $\mathrm{Ba}_{\mathrm{LU}}$ section), except for affecting the contribution of $\mathrm{Ba}_{\mathrm{LU}}$ and Po to La utilization on the $\mathrm{M}$ diet. Lower peak La concentrations on the $\mathrm{M}$ diet and the corresponding increase in rumen $\mathrm{pH}$ allowed Po to compete for La more effectively, especially where the affinity of $\mathrm{Ba}_{\mathrm{LP}}$ for La was reduced below the model value. A similar effect was observed for a lowering of $M_{L a, L a P_{o}}$ (with $0.0040 \mathrm{~mol} / \mathrm{L}$ as a default value, derived in the Po section), simulating an increase in protozoal affinity 
Table 5. Sensitivity of lactic acid (La) production and utilization to changes $( \pm 20 \%)$ in key model parameters for 3 simulated diets ${ }^{1,2}$

\begin{tabular}{|c|c|c|c|c|c|c|c|c|c|c|c|}
\hline \multirow[b]{2}{*}{ Item } & \multirow{2}{*}{$\begin{array}{c}\text { Default model } \\
\text { parameter } \\
\text { value } \\
(\mathrm{mol} / \mathrm{L}, \mathrm{mol} / \mathrm{d})\end{array}$} & \multicolumn{2}{|c|}{ Peak La (mol/L) } & \multicolumn{2}{|c|}{ Minimum La (mol/L) } & \multicolumn{2}{|c|}{$\begin{array}{l}\text { Ba }_{\mathrm{LU}} \text { contribution to } \\
\text { La utilization }\end{array}$} & \multicolumn{2}{|c|}{$\begin{array}{l}\text { Po contribution to } \\
\text { La utilization }{ }^{4}(\%)\end{array}$} & \multicolumn{2}{|c|}{$\begin{array}{l}\text { Maximum Po contribution } \\
\text { to La utilization (\%) }\end{array}$} \\
\hline & & $-20 \%$ & $+20 \%$ & $-20 \%$ & $+20 \%$ & $-20 \%$ & $+20 \%$ & $-20 \%$ & $+20 \%$ & $-20 \%$ & $+20 \%$ \\
\hline Basal model dietary resp & & \multirow{2}{*}{\multicolumn{2}{|c|}{0.0380}} & \multirow{2}{*}{\multicolumn{2}{|c|}{$1.60 \mathrm{E}-07$}} & & & & & & \\
\hline GS & & & & & & \multicolumn{2}{|c|}{86.9} & \multicolumn{2}{|c|}{13.1} & \multicolumn{2}{|c|}{34.3} \\
\hline $\mathrm{M}$ & & \multicolumn{2}{|c|}{0.0130} & \multicolumn{2}{|c|}{$2.40 \mathrm{E}-06$} & \multicolumn{2}{|c|}{71.7} & \multicolumn{2}{|c|}{28.3} & \multicolumn{2}{|c|}{53.5} \\
\hline $\mathrm{SC}$ & & \multicolumn{2}{|c|}{0.0479} & \multicolumn{2}{|c|}{$8.00 \mathrm{E}-09$} & \multicolumn{2}{|c|}{98.3} & \multicolumn{2}{|c|}{$\begin{array}{r}20.0 \\
1.7\end{array}$} & \multicolumn{2}{|c|}{13.8} \\
\hline \multicolumn{12}{|l|}{ Parameter and diet } \\
\hline$M_{H a, A m \mathrm{Ba}_{\mathrm{LP}}}, M_{H a, P s \mathrm{Ba}_{\mathrm{LP}}}$ & $0.090,0.140$ & & & & & & & & & & \\
\hline GS & & 0.0478 & 0.0308 & $1.40 \mathrm{E}-07$ & $1.40 \mathrm{E}-07$ & 89.2 & 86.2 & 10.8 & 13.8 & 29.6 & 38.2 \\
\hline M & & 0.0194 & 0.0108 & $2.70 \mathrm{E}-06$ & $1.90 \mathrm{E}-06$ & 72.2 & 61.4 & 27.8 & 38.6 & 51.1 & 65.0 \\
\hline $\mathrm{SC}$ & & 0.0720 & 0.0326 & $8.40 \mathrm{E}-09$ & $7.80 \mathrm{E}-09$ & 98.5 & 98.1 & 1.5 & 1.9 & 13.7 & 14.1 \\
\hline$M_{L a, A m \mathrm{Ba}_{\mathrm{LU}}}, M_{L a, P s \mathrm{Ba}_{\mathrm{LU}}}$ & $0.0010,0.0016$ & & & & & & & & & & \\
\hline GS & & 0.0367 & 0.0403 & $1.30 \mathrm{E}-07$ & $2.00 \mathrm{E}-07$ & 89.1 & 83.9 & 10.9 & 16.1 & 32.9 & 37.2 \\
\hline $\mathrm{M}$ & & 0.0114 & 0.0147 & $1.90 \mathrm{E}-06$ & $2.80 \mathrm{E}-06$ & 83.2 & 64.4 & 16.8 & 35.6 & 44.3 & 63.0 \\
\hline $\mathrm{SC}$ & & 0.0414 & 0.0505 & $6.90 \mathrm{E}-09$ & $9.40 \mathrm{E}-09$ & 98.6 & 98.1 & 1.4 & 1.9 & 12.2 & 15.4 \\
\hline$M_{L a, L a P o}$ & 0.0040 & & & & & & & & & & \\
\hline GS & & 0.0370 & 0.0382 & $1.30 \mathrm{E}-07$ & $1.70 \mathrm{E}-07$ & 82.0 & 90.0 & 18.0 & 10.0 & 40.9 & 33.5 \\
\hline $\mathrm{M}$ & & 0.0128 & 0.0135 & $2.40 \mathrm{E}-06$ & $2.70 \mathrm{E}-06$ & 59.4 & 82.2 & 40.6 & 17.8 & 67.4 & 44.7 \\
\hline $\mathrm{SC}$ & & 0.0463 & 0.0483 & $8.20 \mathrm{E}-09$ & $8.90 \mathrm{E}-09$ & 98.2 & 98.4 & 1.8 & 1.6 & 19.6 & 9.9 \\
\hline$v_{A m, A m \mathrm{Ba}_{\mathrm{LP}}}^{*}, v_{P s, P_{s} \mathrm{Ba}_{\mathrm{LP}}}^{*}$ & $0.172,0.185$ & & & & & & & & & & \\
\hline GS & & 0.0229 & 0.0501 & $1.30 \mathrm{E}-07$ & $6.70 \mathrm{E}-07$ & 90.2 & 82.9 & 9.8 & 17.1 & 26.2 & 35.7 \\
\hline M & & 0.0114 & 0.0205 & $7.00 \mathrm{E}-07$ & $2.70 \mathrm{E}-06$ & 75.4 & 39.3 & 24.6 & 60.7 & 43.1 & 96.0 \\
\hline $\mathrm{SC}$ & & 0.0225 & 0.0864 & $7.20 \mathrm{E}-09$ & $1.10 \mathrm{E}-08$ & 98.6 & 97.9 & 1.4 & 2.1 & 12.4 & 15.4 \\
\hline$v_{A m L a, A m \mathrm{Ba}_{\mathrm{LU}}}^{*}, v_{P s L a, P s \mathrm{Ba}_{\mathrm{LU}}}^{*}$ & $0.0848,0.0931$ & & & & & & & & & & \\
\hline GS & & 0.0553 & 0.0237 & $6.30 \mathrm{E}-07$ & $8.80 \mathrm{E}-08$ & 62.8 & 91.0 & 37.2 & 9.0 & 63.2 & 23.8 \\
\hline M & & 0.0167 & 0.089 & $3.70 \mathrm{E}-06$ & $1.70 \mathrm{E}-06$ & 3.5 & 85.2 & 96.5 & 14.8 & 98.2 & 36.0 \\
\hline $\mathrm{SC}$ & & 0.0940 & 0.0277 & $8.00 \mathrm{E}-08$ & $6.10 \mathrm{E}-09$ & 94.6 & 98.7 & 5.4 & 1.3 & 15.0 & 9.4 \\
\hline
\end{tabular}

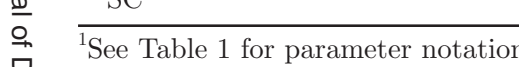

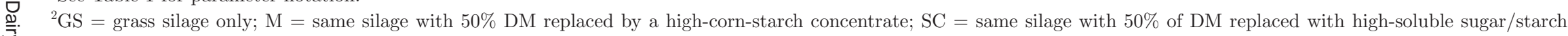
₹

$\stackrel{\curvearrowright}{\circ} \cdot{ }^{3} \mathrm{Ba}_{\mathrm{LU}}=$ La-utilizing bacteria

${ }^{4} \mathrm{Po}=$ protozoa 
for La. This emphasizes how model sensitivity to changes in $M_{L a, L a P o}$ is diet dependent. Variations in $M_{L a, L a P_{o}}$ alter model predictions substantially only where limited La accumulation exits ( $\mathrm{M}$ diet; Po contribution to La utilization: 17.8 to $40.6 \%$ ). The model was most sensitive to changes in the maximum rate of uptake of ammonia and soluble protein by $\mathrm{Ba}_{\mathrm{LP}}$, or $\mathrm{Ba}_{\mathrm{LU}}$ during La utilization. A $20 \%$ increase in $v_{A m, A m B a_{L P}}^{*}$ and $v_{P s, P s \mathrm{Ba}_{\mathrm{LP}}}^{*}$ (with 0.172 and $0.185 \mathrm{~mol} / \mathrm{d}$ as default values, respectively, derived in the $\mathrm{Ba}_{\mathrm{LP}}$ section) returned an increase in peak La concentration of $80 \%$ for the SC diet, $55 \%$ for the $\mathrm{M}$ diet, and $32 \%$ for the GS diet. This reflects the increase in both the simulated quantity of $\mathrm{Ba}_{\mathrm{LP}}$ and the fraction of hexose fermented to $\mathrm{La}(Y L a)$ as the specific growth rate increases. Again, large differences were observed for the contribution of $\mathrm{Ba}_{\mathrm{LU}}$ to La utilization for the $\mathrm{M}$ diet, affirming the fine balance between $\mathrm{Ba}_{\mathrm{Lu}}$ and Po as utilizers of La at lower rumen La concentrations. Increasing the maximum rate of nitrogen uptake by $\mathrm{Ba}_{\mathrm{LU}}\left(v_{A m L a, A m \mathrm{Ba}_{\mathrm{LU}}}^{*}\right.$ and $v_{P s L a, P s \mathrm{Ba}}^{*}$, with 0.0848 and $0.0931 \mathrm{~mol} / \mathrm{d}$ as default values, respectively, derived in the $\mathrm{Ba}_{\mathrm{LU}}$ section) produced an inverse effect to that described for $\mathrm{Ba}_{\mathrm{LP}}$ due to increased growth rates of $\mathrm{Ba}_{\mathrm{LU}}$ leading to an increase in total La utilization.

Simulated time to peak La concentration was insensitive to all parameters tested other than DMI rate. As DMI rate increased from 0.22 to $0.27 \mathrm{~kg}$ of $\mathrm{DM} / \mathrm{min}$, the time to peak La concentration decreased by 21 to 29 min after feeding. The lack of sensitivity of time to peak concentration to other parameters is surprising. However, postprandial sampling frequencies for published data are generally too low to challenge this aspect of model prediction. Hence, observed peak La concentration for different diets are often presented as occurring at the same time (i.e., time to first post-feed sampling; Newbold et al., 1986).

\section{Comparison Between Observed and Predicted Results}

Figure 2 shows that peak La concentration was generally well predicted by the model $\left(\mathrm{R}^{2}=0.96\right.$; RMSPE $=$ $16.96 \%$, random error dominating). As already indicated, the frequency of observation in the studies used for model evaluation limits the scope for testing the ability of the model to simulate time to peak La accumulation. Chamberlain et al. (1983) and Newbold et al. (1986) reported observations every 30 min, whereas Mackie et al. (1984) and Counotte et al. (1983) used a 15-min sampling frequency. The rapid rate of La production and utilization meant that the first sampling time was often associated with peak La concentration. However,

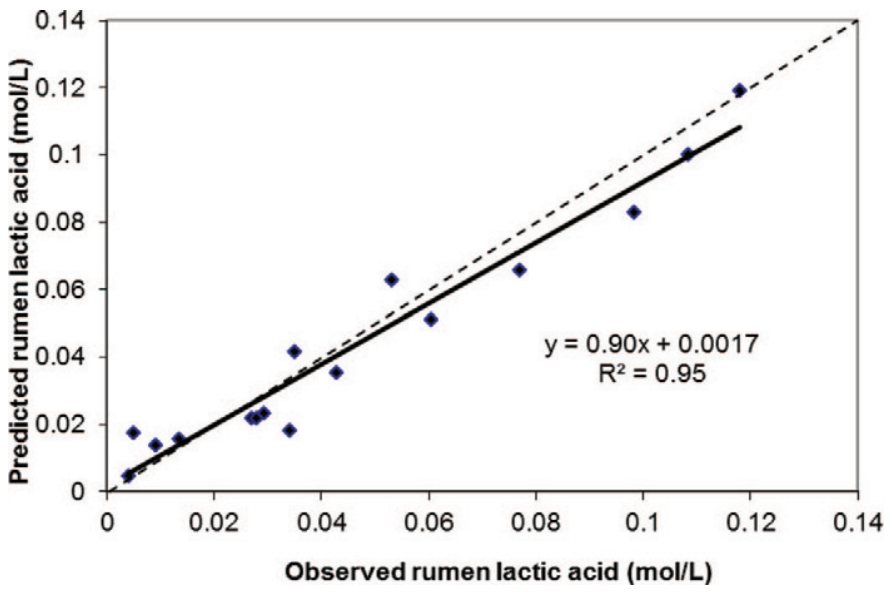

Figure 2. Regression of observed and predicted peak rumen lactic acid concentration for cows (Chamberlain et al., 1983; Counotte et al., 1983) and sheep (Mackie et al., 1984; Newbold et al., 1986), where the dashed line is the line of equality and the solid line is the regression line. Observed mean $=0.0464 \mathrm{~mol} / \mathrm{L}$; predicted mean $=0.0435$ $\mathrm{mol} / \mathrm{L}$; square root of the mean square prediction error $(\mathrm{RMSPE})=$ $16.96 \%$; error due to overall bias (ECT) $=5.86 \%$; error due to deviation of the regression slope from unity $(\mathrm{ER})=4.80 \%$; error due to the disturbance (random error, $\mathrm{ED})=89.38 \%$. Color version available in the online PDF.

one would expect differences in nutrient composition and eating pattern between diets to influence the time at which peak concentration is observed. Therefore, only general observations can be made regarding the simulation of the rate of La accumulation for the diets used in model evaluation. Only Counotte et al. (1983) describe DMI rate (5.5 kg of concentrate DM in $6 \mathrm{~min})$. Therefore, Figure 3 represents the only simulation without assumptions regarding intake rate.

Both Figures 3 and 4 demonstrate how, despite reliable simulation of peak La concentration, the model had difficulty describing the pattern of postprandial La accumulation over time. For the diet of Counotte et al. (1983) the model underpredicted the rate of La accumulation. However, the rate of La removal was similar to the observed data. The reason for the delay in simulated peak La concentration was due to a slow increase in the proportion of hexose fermented to La by $\mathrm{Ba}_{\mathrm{LP}}$. The $Y L a$ increased immediately to 0.33 after feeding due to an increase in hexose availability and, hence, growth rate of $\mathrm{Ba}_{\mathrm{LP}}$ (Figure 5). However, the rate of $\mathrm{pH}$ decline (Figure 6 ) was too slow to facilitate a rapid increase in $Y L a$ (see Equation 3), despite good agreement between observed and predicted VFA concentration (data not shown). Therefore, poor ability to predict the rate of $\mathrm{pH}$ decline delayed the time to peak La concentration. This highlights the need for improved methods of $\mathrm{pH}$ prediction that consider factors other than VFA and La concentrations in the rumen. Briggs et al. (1957) showed that the relationship between 


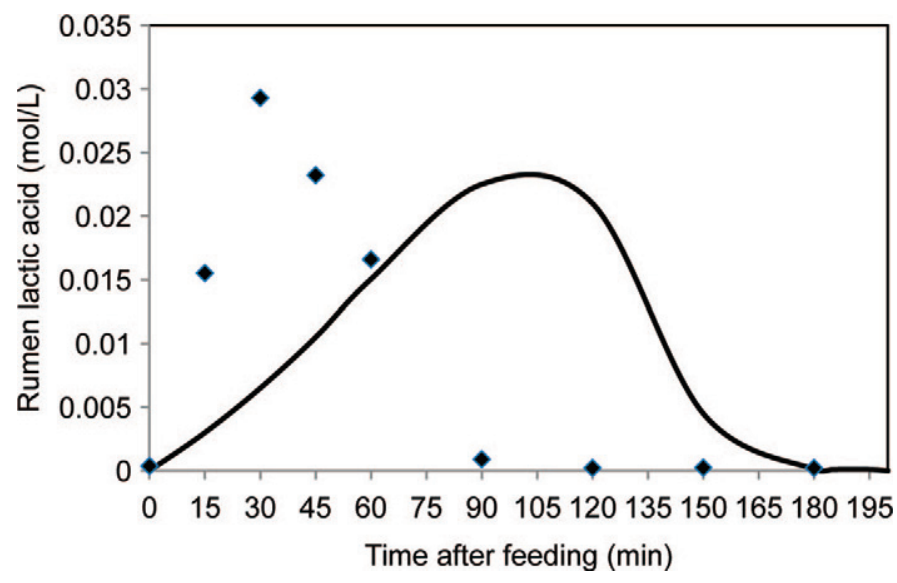

Figure 3. A plot showing observed $(\diamond)$ and simulated (solid line) rumen lactic acid accumulation after feeding $6 \mathrm{~kg}$ of concentrate to a dairy cow for the diet from Counotte et al. (1983). Color version available in the online PDF.

rumen $\mathrm{pH}, \mathrm{VFA}$, and La concentrations in sheep was influenced by ammonia level and salivary secretion, whereas McBurney et al. (1983) demonstrated the large variation in buffering capacity associated with a range of ruminant feedstuffs. Argyle (1989) proposed the use of multiple regression equations between $\mathrm{pH}$ and VFA concentration, depending on dietary buffering capacity. More recently, Dijkstra et al. (2012) reviewed a range of factors important in determining and regulating rumen $\mathrm{pH}$, and identified that even decades later, accurate prediction of rumen $\mathrm{pH}$ is still a limiting factor of current mechanistic rumen models. Until these underlying problems are addressed, progress in this area will be limited.

In contrast to the model predictions on the Counotte et al. (1983) data, the model simulates a more rapid rise in post-feeding La concentration for the study of Chamberlain et al. (1983) for cows fed a GS diet (Figure 4). Dietary La is a major contributor to this rapid accumulation. The overestimated rate of decline in La concentration for this diet may indicate underestimation of La production in the rumen, overestimation of La removal, or errors in model input parameters relating to eating pattern. However, a reduced intake rate would also reduce the prediction of peak La concentration and, therefore, inaccurate simulation of La metabolism between 70 and $130 \mathrm{~min}$ after feeding is a more likely cause of error. The fraction of Po utilizing La never increased above 0.4 after 50 min after feeding and soon declined to less than 0.05 at $100 \mathrm{~min}$. However, the fraction of $\mathrm{Ba}_{\mathrm{LU}}$ utilizing La remained above 0.5 until 85 min after feeding. As a result, the simulated contribution of $\mathrm{Ba}_{\mathrm{LU}}$ to total La removal from the rumen remained above $90 \%$ for the post-feeding period. Hence,

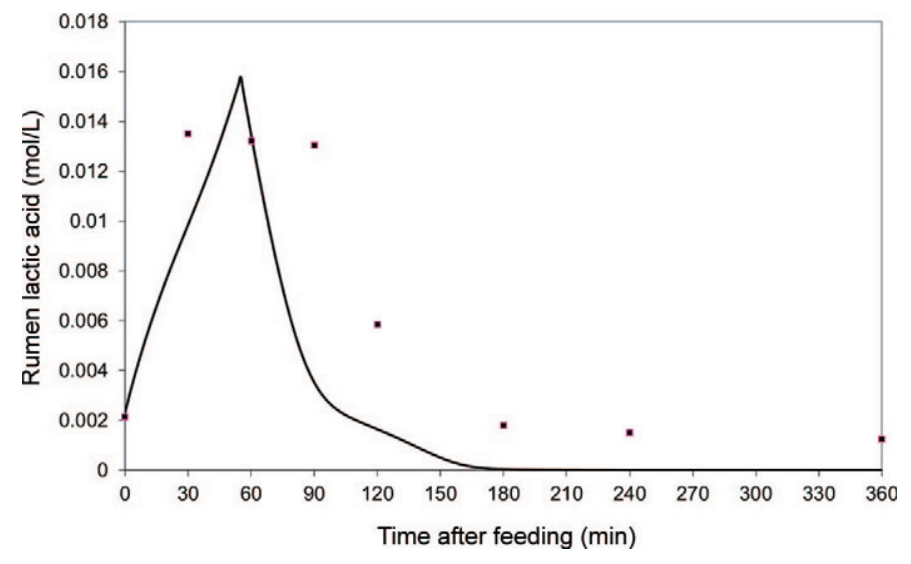

Figure 4. Observed (ם) and simulated (solid line) rumen lactic acid accumulation after feeding grass silage to dairy cows for the diet fed by Chamberlain et al. (1983). Color version available in the online PDF.

if the model overpredicted the rate of La removal, it was due to estimates of the rate of La uptake by $\mathrm{Ba}_{\mathrm{LU}}$.

Figure 7 demonstrates the generally good agreement between observed and predicted La production and utilization rates for the high-concentrate diet of Mackie et al. (1984). Simulated time to peak rates of production and utilization was slower than observed, although the difference was small $(<20 \mathrm{~min})$. The predicted delay between peak production and utilization was approximately half of that observed, although, as with observations on peak La concentration, the low monitoring frequency for the observed data prevented a comprehensive comparison. Simulated peak utilization rate was $25 \%$ lower than observed, although the decline from the peak was delayed relative to that observed. From 150 min after feeding, simulated La production

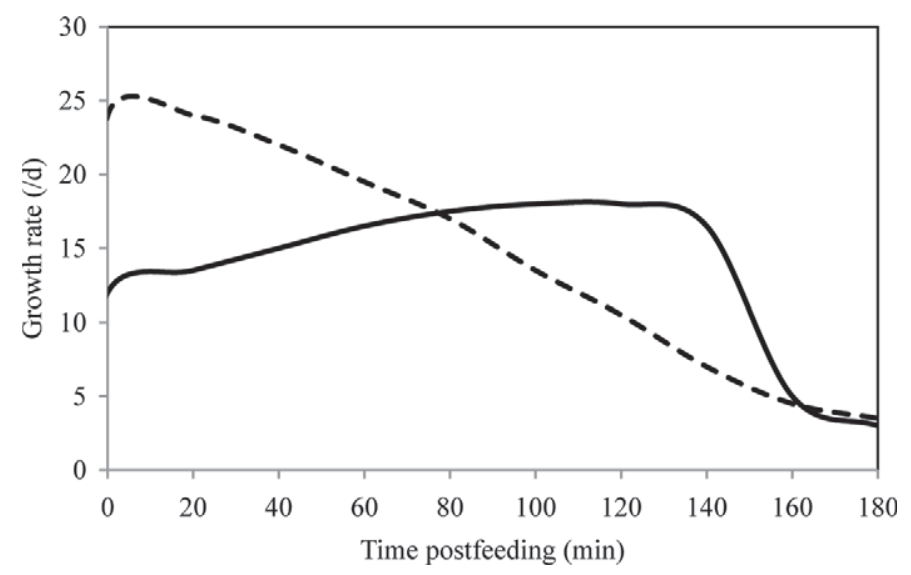

Figure 5. Simulated amylolytic bacterial fractional growth rates [where the solid line is lactic acid-utilizing bacteria $\left(\mathrm{Ba}_{\mathrm{LU}}\right)$ and the dashed line is lactic acid-producing bacteria $\left.\left(\mathrm{Ba}_{\mathrm{LP}}\right)\right]$ after feeding $6 \mathrm{~kg}$ of concentrate to a dairy cow for the diet from Counotte et al. (1983). 


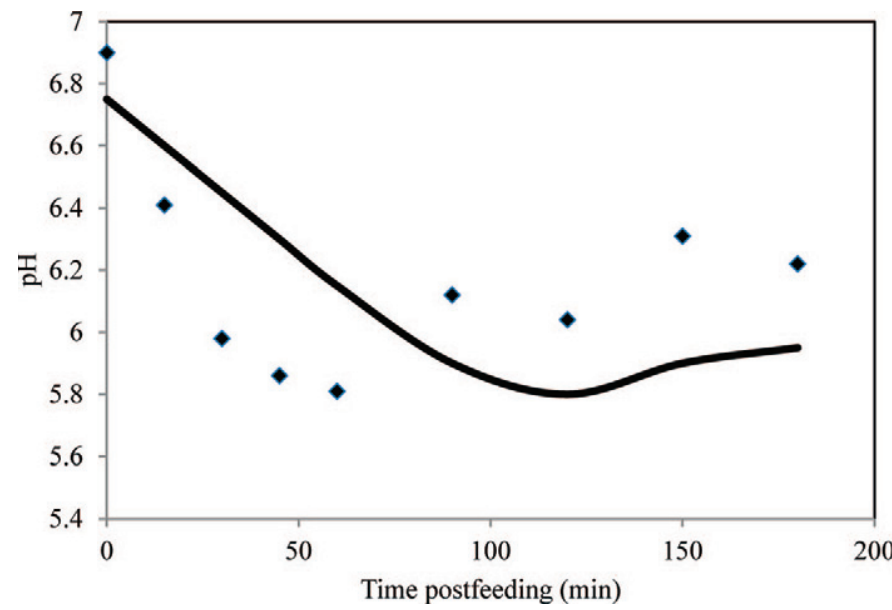

Figure 6. A plot of observed and simulated rumen $\mathrm{pH}$ change after feeding $6 \mathrm{~kg}$ of concentrate to a dairy cow for the diet from Counotte et al. (1983), where represents the observed data and the solid line represents model predictions. Color version available in the online PDF.

was lower than that observed by a factor of $8(2.0 \times$ $10^{-5}$ vs. $2.5 \times 10^{-6} \mathrm{~mol} / \mathrm{L}$ per minute). This indicates that the very low simulated basal La concentrations (Table 5) resulted from underprediction of La production rather than overprediction of utilization in the rumen.

Figure 8 shows how the specific growth rate of $\mathrm{Ba}_{\mathrm{LP}}$ rose above that of $\mathrm{Ba}_{\mathrm{LU}}$ for 40 min after feeding and then declined to marginally below that of $\mathrm{Ba}_{\mathrm{Lu}}$ as amylolytic hexose returned to prefeeding levels. As expected, the peak rate of growth for $\mathrm{Ba}_{\mathrm{LU}}$ coincided with peak La concentration (Figure 8) and the highest fraction of $\mathrm{Ba}_{\mathrm{LU}}$ utilizing La (Figure 9). The slower

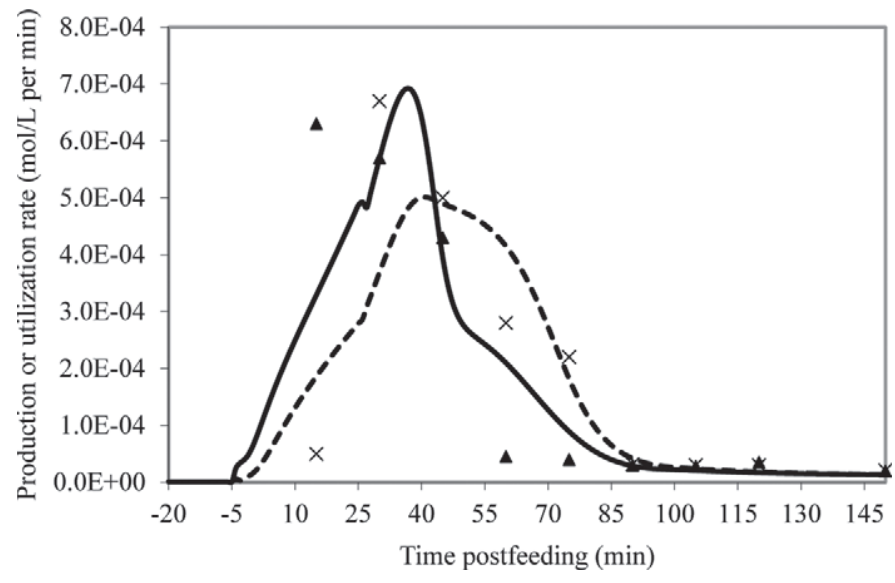

Figure 7. A comparison of simulated and observed production and utilization of lactic acid in the rumen of sheep fed the high-concentrate diet from Mackie et al. (1984), where $\boldsymbol{\Delta}$ is the observed production, $\times$ is the observed utilization, the solid line is simulated production, and the dashed line is simulated utilization ( $\mathrm{mol} / \mathrm{L}$ per minute). and smaller increase in the fraction of Po utilizing La reflects the lower protozoal affinity for La. Mackie et al. (1984) also reported mean microbial counts across all 4 diets. However, direct comparisons to model predictions for bacterial presence cannot be made because Mackie et al. (1984) did not differentiate between La producers and other $\mathrm{Ba}$, and $\mathrm{Ba}_{\mathrm{LU}}$ represented more than 1 microbial group, depending on energy substrate. The model did not simulate increased protozoal presence with increased concentrate intake, with the high-roughage diet yielding a similar mean protozoal population to that of the high-concentrate diet (35 vs. $31 \mathrm{~g})$. Simulated lucerne hay and intermediate diets yielded less Po (21 and $28 \mathrm{~g}$, respectively). Protozoal presence on the high-concentrate diet was limited by periods of low rumen $\mathrm{pH}$ (minimum $\mathrm{pH}=5.76$; mean $\mathrm{pH}=6.24)$ in comparison with the high-roughage diet (minimum $\mathrm{pH}=6.21$; mean $\mathrm{pH}=6.57$; see Equation $5)$. Our results are in qualitative agreement with the results of Wanapat et al. (2014) for dairy steers fed diets differing in roughage-to-concentrate ratio (0.8:0.2 up to $0.2: 0.8$. Protozoal numbers did not change with roughage-to-concentrate ratio, but quantitative PCR based on 16S RNA showed that M. elsdenii increased with increase in roughage-to-concentrate ratio, and did so more rapidly with an increase from 0.4:0.6 to 0.2:0.8 than with an increase from 0.8:0.2 to 0.4:0.6.

It is clear from Figures 3 and 4 and Table 4 that the basal concentration of La in the rumen was generally underpredicted. One explanation is that the level of La production during the mid-feeding cycle, associated with normal-to-low amylolytic hexose concentration, was underestimated. The $Y L a_{\min }$ was taken from in vitro incubations performed by Russell and Baldwin (1979a) using Strep. bovis. The contribution of lactobacilli undergoing homolactic fermentation could increase the total level of La production from $\mathrm{Ba}_{\mathrm{LP}}$. However, lactobacilli are unlikely to be present in large numbers on typical diets at this stage of the diurnal feeding cycle. Another explanation involves the contribution of Po to La production (Ellis et al., 1991). The model only considers Po as La utilizers. Ellis et al. (1991) showed that the vestibuliferid Dasytricha ruminantium produced La as a principal product of carbohydrate fermentation in vitro. Production of La by vestibuliferids during the mid-feeding cycle could cause higher basal La concentrations than are predicted by the model. However, adequate data defining the propensity for a range of protozoal species to produce La are not available at present. Even if data were sufficient to parameterize the model, a more reductionist approach may be needed because the entodiniomorphid Po are the major utilizers of La, whereas the evidence of Ellis et al. (1991) suggests the vestibuliferid Po may be the important 


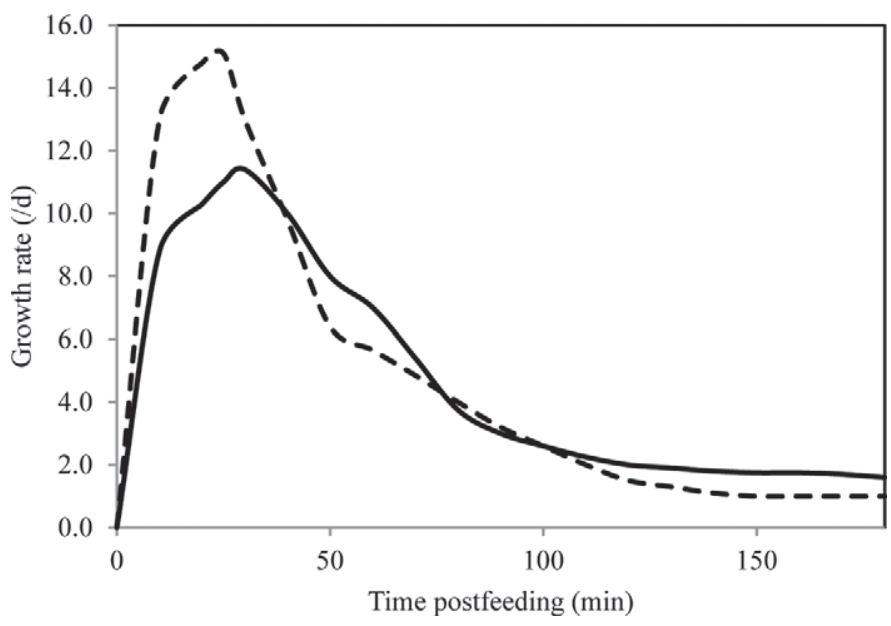

Figure 8. Simulated change in specific growth rate of amylolytic bacteria for the high-concentrate diet from Mackie et al. (1984), where the dashed line represents lactic acid-producing bacteria $\left(\mathrm{Ba}_{\mathrm{LP}}\right)$ and the solid line represents lactic acid-utilizing bacteria $\left(\mathrm{Ba}_{\mathrm{LU}}\right)$.

La producers. For some diets, such as those based on barley and hay (Newbold et al., 1986), there is a low level of rumen-available nitrogen. This limits bacterial growth rate, including that of $\mathrm{Ba}_{\mathrm{LP}}$, despite adequate or high levels of amylolytic hexose. This elevates the hexose fermentation for non-growth purposes, yielding VFA. However, if $\mathrm{pH}$ is not reduced sufficiently, the low growth rate limits $Y L a$ and simulated La production is lower than expected. This indicates the need for provision to account for increases in $Y L a$ where amylolytic hexose is in excess but nitrogen availability limits the growth of $\mathrm{Ba}_{\mathrm{LP}}$.

The simulated fate of La was dependent upon La concentration in the rumen. Figure 10 shows that $\mathrm{Ba}_{\mathrm{LU}}$ was the major sink for rumen La at both peak and basal La concentrations. However, the relative contribution of $\mathrm{Ba}_{\mathrm{LU}}$ increased immediately after feeding and then declined as La concentration approached its peak. The simulated contribution of Po to La utilization was most significant as La concentration approached peak levels. Apart from the first $10 \mathrm{~min}$ after feeding, the contributions of passage and absorption to the removal of La from the rumen were only between 2 and $9 \%$ and 1 and $2 \%$, respectively. Therefore, the simulations are in agreement with Gill et al. (1986), who accounted for 90\% of total La flow through fermentation to VFA in GS-fed sheep. Hence, in support of Gill et al. (1986), it would seem that the direct contribution of rumen La to glucose synthesis by the tissues is minimal. Because the stoichiometry of La fermentation is fixed within the model, the indirect contribution of rumen La to tissue glucose synthesis via propionate increases in proportion to La production. In reality, this may be an oversimplification, as the stoichiometry of La fermentation is

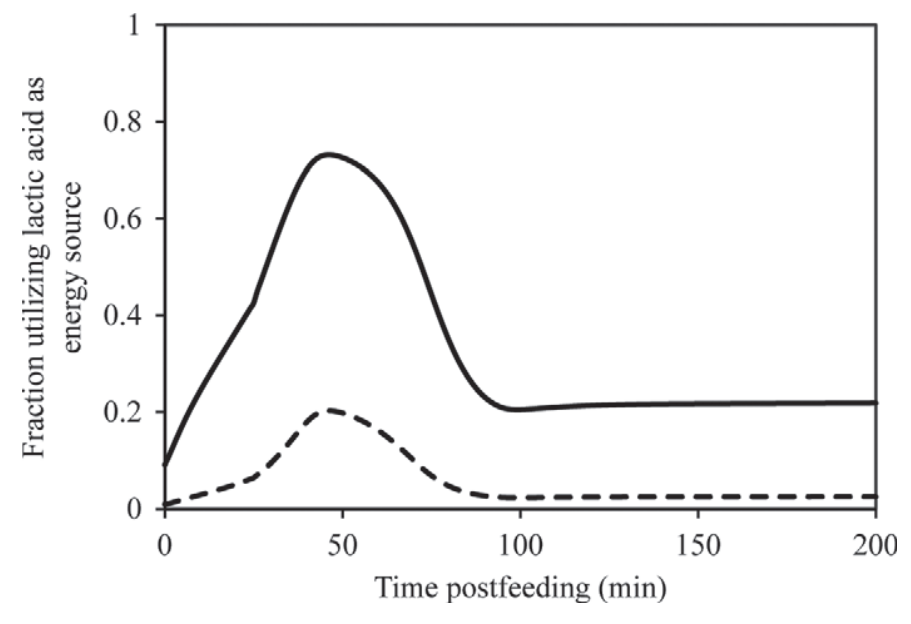

Figure 9. Simulated fraction of lactic acid-utilizing bacteria ( $\left.\mathrm{Ba}_{\mathrm{LU}}\right)$ and protozoa (Po) utilizing lactic acid as an energy source for the highconcentrate diet from Mackie et al. (1984), where the solid line is $\mathrm{Ba}_{\mathrm{LU}}$ and the dashed line is Po.

likely to change with rumen La concentration and rumen pH (Counotte et al., 1981).

Malestein et al. (1984) showed that the risk of lactic acidosis in dairy cows was correlated with dietary glucose, fructose, and soluble protein. Malestein et al. (1984) commented on the influence of soluble protein as striking, especially because La is not a major product of protein fermentation. To investigate these observations, the model was used to simulate the effects of changing levels of soluble protein for the diet fed by Counotte et al. (1983). Where the fraction of soluble protein in the concentrate was increased by $25 \%$ at the expense of RUP, the simulated peak La concentration increased marginally from 0.0252 to $0.0258 \mathrm{~mol} / \mathrm{L}$. However,

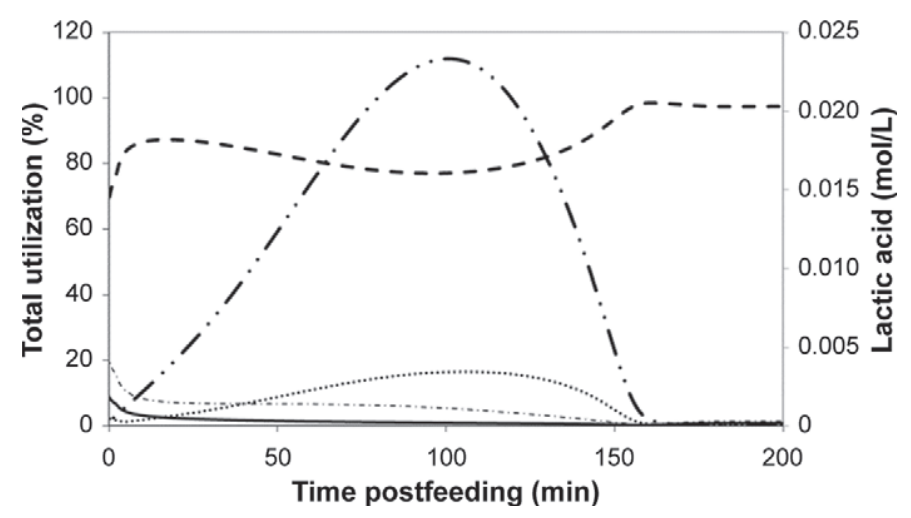

Figure 10. Simulated fate of lactic acid (La) within the rumen after feeding $6 \mathrm{~kg}$ of concentrate to a dairy cow for the diet from Counotte et al. (1983), where the contribution to La utilization by various groups is shown by the dashed line for lactic acid-utilizing bacteria $\left(\mathrm{Ba}_{\mathrm{LU}}\right)$ and the dotted line for protozoa $(\mathrm{Po})$. The solid line represents absorption, - - - represents passage, and - -. - represents La concentration. 
when soluble protein was reduced by $25 \%$, the simulated peak rumen La concentration declined by over $12 \%$ to $0.0222 \mathrm{~mol} / \mathrm{L}$. This confirms the observations of Malestein et al. (1984) and can be explained by the increase in specific growth rate of $\mathrm{Ba}_{\mathrm{LP}}$ as protein availability increases. This increase in specific growth rate leads to an increase in $Y L a$ as well as the total number of $\mathrm{Ba}_{\mathrm{LP}}$. However, in addition to the effect described by Malestein et al. (1984), the model showed a diminishing returns response as soluble protein became nonlimiting to $\mathrm{Ba}$ growth. Although $\mathrm{Ba}_{\mathrm{LU}}$ are also dependent upon levels of soluble protein availability for growth, their comparatively slow maximum rate of soluble protein uptake limits the effect of increasing protein availability on rumen La utilization.

The infusion study of Newbold et al. (1986) indicates a major decline in the rate of La utilization and removal from the rumen following defaunation. In keeping with experimental observations, the peak La concentrations predicted by the model were similar following defaunation. However, in contrast to the observed data, the rate of decline during the immediate period after peak La concentration was unaffected by defaunation. Such differences between observed and predicted data suggest a more complex role of Po in rumen La metabolism than is currently afforded by the model. It is unlikely that changes in parameter values (Table 5) can explain the differences observed. Protozoa influence rumen La metabolism either through engulfment of NSC, preventing immediate fermentation to La (Jouany et al., 1988), or via direct La uptake. The model represents both mechanisms, although for simulations involving the data of Newbold et al. (1986) the direct uptake of La is most significant due to the lack of endogenous La production. Therefore, the model seems to overpredict La utilization by $\mathrm{Ba}_{\mathrm{LU}}$ following defaunation. In reality, competition between various bacterial species within $\mathrm{Ba}_{\mathrm{LU}}$ for hexose, nitrogen, and other nutrients may limit the growth of specialist La utilizers such as M. elsdenii (Russell and Baldwin, 1979b). Protozoal and bacterial metabolism differ sufficiently within the rumen for the La-utilizing bacteria to be unable to completely replace the role of Po in La metabolism following defaunation. Hence, the reliance on La as the principle determinant of competition between $\mathrm{Ba}_{\mathrm{LU}}$ and Po is insufficient for simulating the defaunated state. The data of Newbold et al. (1986) indicate a larger contribution of Po to La metabolism than is described by the model.

\section{Future Considerations}

A mechanistic model such as the one described is able to identify areas where biological knowledge is lacking (Thornley and France, 2007). In this instance, it is clear that certain aspects of rumen La metabolism exist that require further research. In particular, the contribution of Po to the process and their interaction with La-utilizing bacteria is still unclear. Furthermore, the mechanisms involved in the metabolism of basal La concentrations in the prefeeding period need investigation. Determination of rumen $\mathrm{pH}$ from VFA and La concentration would benefit from quantification of rumen-buffering capacity across a range of dietary inputs. This would be particularly important if a spiraling nature of lactic acidosis (Nocek, 1997) were confirmed. As our understanding of the underlying biology increases, it should be possible to reorganize the La model at a lower level of aggregation, and in doing so represent the biology more completely. For example, the explicit description of individual La isomers could account more precisely for the differences in La accumulation across a range of diets (Giesecke and Stangassinger, 1980). A more reductionist approach is also required for the simulation of the transient, non-steady state, metabolic responses associated with changes in microbial composition observed before dietary adaptation (Malestein et al., 1984; Harmon et al., 1985). The sensitivity analysis highlighted the need to describe the eating pattern for the prediction of time to peak La concentration. Such diet-specific parameters are not available on farm. Therefore, a procedure to define the rate of DMI based on the diet composition and feeding regimen is needed, although prediction of the total La load is more important than time to peak concentration.

\section{CONCLUSIONS}

The ability of the mechanistic model to simulate peak rumen La concentration is encouraging. The model could form a useful tool in the evaluation of diets with regard to their propensity for lactic acidosis. The model has supported several current concepts relating to the metabolism of La in the rumen. In particular, the model highlights the relationship between NSC availability and La production. Also, the lack of significance of absorbed La to glucose synthesis is confirmed by the model, along with the influence of soluble protein as a stimulant to La production where protein availability is limiting. Further modeling research is required to account for the fluctuation in rumen $\mathrm{pH}$ according to dietary buffering capacity. The integration of current concepts on rumen La metabolism with an existing mechanistic rumen model has helped to provide an understanding of the nutritional factors leading to lactic acidosis and the model could be used to evaluate ruminant diets for their potential acidosis risk. 


\section{ACKNOWLEDGMENTS}

This research was partially funded by the Department for Environment, Food and Rural Affairs (Defra, London, UK) project LS3656. Partial funding was also obtained from the European Union (under grant agreement numbers FP7-266018 and FP7-211606), Dairy Farmers of Canada (Ottawa, ON, Canada), and the Natural Sciences and Engineering Research Council of Canada (NSERC, Ottawa, ON, Canada) Research Chairs program.

\section{REFERENCES}

Argyle, J. L. 1989. Modelling rumen water kinetics and $\mathrm{pH}$ effects. Pages 65-78 in Proceedings of the 3rd International Workshop on Modelling Digestion and Metabolism in Farm Animals. A. B. Robson and D. P. Poppi, ed. Lincoln University, Canterbury, New Zealand.

Baldwin, R. L. 1995. Modeling Ruminant Digestion and Metabolism. Chapman and Hall, London, UK.

Bannink, A., H. De Visser, J. Dijkstra, and J. France. 1997. Impact of diet-specific input parameters on simulated rumen function. J. Theor. Biol. 184:371-384.

Beauchemin, K., and G. Penner. 2009. New developments in understanding ruminal acidosis in dairy cows. Pages $6-17$ in Proc. TriState Dairy Nutrition Conference, Fort Wayne, IN. Ohio State University, Dept. of Animal Science, Columbus.

Bibby, J., and H. Toutenburg. 1977. Prediction and Improved Estimation in Linear Models. John Wiley and Sons, London, UK.

Black, J. L., D. E. Beever, G. J. Faichney, B. R. Howarth, and N. M. Graham. 1981. Simulation of the effects of rumen function on the flow of nutrients from the stomach of sheep: Part 1-Description of a computer program. Agric. Syst. 6:195-219.

Bosch, M. W., S. Tamminga, G. Post, C. P. Leffering, and J. M. Muylaert. 1992. Influence of stage of maturity of grass silages on digestion processes in dairy cows. 1. Composition, nylon bag degradation rates, fermentation characteristics, digestibility and intake. Livest. Prod. Sci. 32:245-264.

Braun, U., T. Rihs, and U. Schefer. 1992. Ruminal lactic acidosis in sheep and goats. Vet. Rec. 130:343-349.

Briggs, P. K., J. P. Hogan, and R. L. Reid. 1957. Effect of volatile fatty acids, lactic acid, and ammonia on rumen $\mathrm{pH}$ in sheep. Aust. J. Agric. Res. 8:674-690.

Calsamiglia, S., M. Blanch, A. Ferret, and D. Moya. 2012. Is subacute ruminal acidosis a $\mathrm{pH}$ related problem? Causes and tools for its control. Anim. Feed Sci. Technol. 172:42-50.

Chamberlain, D. G., P. C. Thomas, and F. J. Anderson. 1983. Volatile fatty acid proportions and lactic acid metabolism in the rumen in sheep and cattle receiving silage diets. J. Agric. Sci. 101:47-58.

Chilibroste, P., J. Dijkstra, P. H. Robinson, and S. Tamminga. 2008. A simulation model "CTR Dairy" to predict supply of nutrients in dairy cows managed under discontinuous feeding patterns. Anim. Feed Sci. Technol. 143:148-173.

Chilibroste, P., J. Dijkstra, and S. Tamminga. 2001. Design and evaluation of a non-steady state rumen model. Neth. J. Agric. Sci. 49:297-312.

Coleman, G. S., and D. C. Sandford. 1979. The engulfment and digestion of mixed rumen bacteria and individual bacterial species by single and mixed species of rumen ciliate protozoa grown in vivo. J. Agric. Sci. 92:729-742.

Counotte, G. H. M., A. Lankhorst, and R. A. Prins. 1983. Role of DLlactic acid as an intermediate in rumen metabolism of dairy cows. J. Anim. Sci. 56:1222-1235.

Counotte, G. H. M., R. A. Prins, R. H. A. M. Janssen, and M. J. A. deBie. 1981. Role of Megasphaera elsdenii in the fermentation of
DL- $\left[2-{ }^{13} \mathrm{C}\right]$ lactate in the rumen of dairy cattle. Appl. Environ. Microbiol. 42:649-655.

Danfær, A., P. Huhtanen, P. Udén, J. Sveinbjörnsson, and H. Volden. 2006. The Nordic dairy cow model, Karoline-Description. Pages 383-406 in Nutrient Digestion and Utilization in Farm Animals: Modelling Approaches. E. Kebreab, J. Dijkstra, A. Bannink, W. J. J. Gerrits, and J. France, ed. CABI Publishing, Oxfordshire, UK.

Dijkstra, J. 1994. Simulation of the dynamics of protozoa in the rumen. Br. J. Nutr. 72:679-699.

Dijkstra, J., J. L. Ellis, E. Kebreab, A. B. Strathe, S. López, J. France, and A. Bannink. 2012. Ruminal pH regulation and nutritional consequences of low pH. Anim. Feed Sci. Technol. 172:22-33.

Dijkstra, J., J. A. N. Mills, and J. France. 2002. The role of dynamic modelling in understanding the microbial contribution to rumen function. Nutr. Res. Rev. 15:67-90.

Dijkstra, J., H. D. St. C. Neal, D. E. Beever, and J. France. 1992. Simulation of nutrient digestion, absorption and outflow in the rumen: Model description. J. Nutr. 122:2239-2256.

Ding, Z., and Y. Xu. 2006. A model for exploring lactic acidosis: 1. Model description. Belg. J. Zool. 136:117-124.

Dunlop, R. H., and P. B. Hammond. 1965. D-Lactic acidosis of ruminants. Ann. N. Y. Acad. Sci. 119:1109-1132.

Ellis, J. E., P. S. McIntyre, M. Saleh, A. G. Williams, and D. Lloyd. 1991. Influence of $\mathrm{CO}_{2}$ and low concentrations of $\mathrm{O}_{2}$ on fermentative metabolism of the rumen ciliate Dasytricha ruminantium. J. Gen. Microbiol. 137:1409-1417.

Elsden, S. R. 1945. The fermentation of carbohydrates in the rumen of the sheep. J. Exp. Biol. 22:51-62.

France, J., J. H. M. Thornley, and D. E. Beever. 1982. A mathematical model of the rumen. J. Agric. Sci. 99:343-353.

Ghorban, K. Z., K. L. Knox, and G. M. Ward. 1966. Concentrations of volatile fatty acids and lactic acid in the rumen as influenced by diet and post-feeding time. J. Dairy Sci. 49:1515-1518.

Giesecke, D., and M. Stangassinger. 1980. Lactic acid metabolism. Pages 523-539 in Physiology and Metabolism in Ruminants. AVI Publ. Co., Westport, CT.

Gill, M., R. C. Siddons, and D. E. Beever. 1986. Metabolism of lactic acid isomers in the rumen of silage-fed sheep. Br. J. Nutr. 55:399-407.

Harmon, D. L., R. A. Britton, R. L. Prior, and R. A. Stock. 1985. Net portal absorption of lactate and volatile fatty acids in steers experiencing glucose-induced acidosis or fed a $70 \%$ concentrate diet ad libitum. J. Anim. Sci. 60:560-569.

Hyldgaard-Jensen, J., and M. G. Simesen. 1966. Grutforgiftning hos kvaeg. Nord. Vet. Med. 18:73-94.

Jami, E., and I. Mizrahi. 2012. Composition and similarity of bovine rumen microbiota across individual animals. PLoS ONE 7:e33306.

Jouany, J. P., D. I. Demeyer, and J. Grain. 1988. Effect of defaunating the rumen. Anim. Feed Sci. Technol. 21:229-265.

Klieve, A. V., D. Hennessy, D. Ouwerkerk, R. J. Forster, R. I. Mackie, and G. T. Attwood. 2003. Establishing populations of Megasphaera elsdenii YE 34 and Butyrivibrio fibrisolvens YE 44 in the rumen of cattle fed high grain diets. J. Appl. Microbiol. 95:621-630.

Leedle, J. A. Z., M. P. Bryant, and R. B. Hespell. 1982. Diurnal variations in bacterial numbers and fluid parameters in ruminal contents of animals fed low- or high-forage diets. Appl. Environ. Microbiol. 44:402-412.

Mackie, R. I., F. M. C. Gilchrist, and S. Heath. 1984. An in vivo study of ruminal micro-organisms influencing lactate turnover and its contribution to volatile fatty acid production. J. Agric. Sci. 103:37-51.

Malestein, A., A. T. van't Klooster, R. A. Prins, and G. H. M. Counotte. 1984. Concentrate feeding and ruminal fermentation 3. Influence of concentrate ingredients on $\mathrm{pH}$, on DL-lactic acid concentration in rumen fluid of dairy cows and on dry matter intake. Neth. J. Agric. Sci. 32:9-21.

McBurney, M. I., P. J. Van Soest, and L. E. Chase. 1983. Cation exchange capacity and buffering capacity of neutral-detergent fibres. J. Sci. Food Agric. 34:910-916. 
Møller, P. D., L. Diernæs, J. Sehested, J. Hyldgaard-Jensen, and E. Skadhauge. 1997. Lactate transport across the bovine rumen epithelium in vitro. Zentralbl. Veterinärmed. A 44:31-38.

Nagaraja, T. G., and E. C. Titgemeyer. 2007. Ruminal acidosis in beef cattle: The current microbiological and nutritional outlook. J. Dairy Sci. 90(E. Suppl.):E17-E38.

Nagaraja, T. G., and G. Towne. 1990. Ciliated protozoa in relation to ruminal acidosis and lactic acid metabolism. Pages 187-194 in The Rumen Ecosystem: The Microbial Metabolism and its Regulation. S. Hoshino, R. Onodera, H. Minato, and H. Itabashi, ed. SpringerVerlag, New York, NY

Newbold, C. J., D. G. Chamberlain, and A. G. Williams. 1986. The effects of defaunation on the metabolism of lactic acid in the rumen. J. Sci. Food Agric. 37:1083-1090.

Newbold, C. J., A. G. Williams, and D. G. Chamberlain. 1987. The in vitro metabolism of D,L-lactic acid by rumen microorganisms. J. Sci. Food Agric. 38:9-18.

Nocek, J. E. 1997. Bovine acidosis: Implications on laminitis. J. Dairy Sci. 80:1005-1028.

Nocek, J. E., and A. L. Grant. 1987. Characterization of in situ nitrogen and fiber digestion and bacterial nitrogen contamination of hay crop forages preserved at different dry matter percentages. J. Anim. Sci. 64:552-564.

Nocek, J. E., and S. Tamminga. 1991. Site of digestion of starch in the gastrointestinal tract of dairy cows and its effect on milk yield and composition. J. Dairy Sci. 74:3598-3629.

NRC. 2001. Nutrient Requirements of Dairy Cattle. 7th rev. ed. National Academies Press, Washington, DC.

Oetzel, G. R., K. V. Nordlund, and E. F. Garett. 1999. Effect of ruminal $\mathrm{pH}$ and stage of lactation on ruminal lactate concentration in dairy cows. J. Dairy Sci. 82(Suppl. 1):35.

Ouwerkerk, D., A. V. Klieve, and R. J. Forster. 2002. Enumeration of Megasphaera elsdenii in rumen contents by real-time Taq nuclease assay. 2002. J. Appl. Microbiol. 92:753-758.

Owens, F. N., D. S. Secrist, W. J. Hill, and D. R. Gill. 1998. Acidosis in cattle: A review. J. Anim. Sci. 76:275-286.

Phillipson, A. T., and R. A. McAnally. 1942. Studies on the fate of carbohydrates in the rumen of sheep. J. Exp. Biol. 19:199-214.

Pitt, R. E., J. S. Van Kessel, D. G. Fox, A. N. Pell, M. C. Barry, and P. J. Van Soest. 1996. Prediction of ruminal volatile fatty acids and $\mathrm{pH}$ within the net carbohydrate and protein system. J. Anim. Sci. 74:226-244.

Plaizier, J. C., D. O. Krause, G. N. Gozho, and B. W. McBride. 2008. Subacute ruminal acidosis in dairy cows: The physiological causes, incidence and consequences. Vet. J. 176:21-31.

Russell, J. B., and R. L. Baldwin. 1979a. Comparison of maintenance energy expenditures and growth yields among several rumen bacteria grown on continuous culture. Appl. Environ. Microbiol. $37: 537-543$.

Russell, J. B., and R. L. Baldwin. 1979b. Comparison of substrate affinities among several rumen bacteria: A possible determinant of rumen bacterial competition. Appl. Environ. Microbiol. 37:531536.

Russell, J. B., M. A. Cotta, and D. B. Dombrowski. 1981. Rumen bacterial competition in continuous culture: Streptococcus bovis versus Megasphaera elsdenii. Appl. Environ. Microbiol. 41:1394-1399.
Russell, J. B., F. J. Delfino, and R. L. Baldwin. 1979. Effects of combinations of substrates on maximum growth rates of several rumen bacteria. Appl. Environ. Microbiol. 37:544-549.

Russell, J. B., and D. B. Dombrowski. 1980. Effect of pH on the efficiency of growth by pure cultures of rumen bacteria in continuous culture. Appl. Environ. Microbiol. 39:604-610.

SAS Institute. 2000. SAS User's Guide: Statistics. SAS Institute Inc. Cary, NC.

Stewart, C. S. 1992. Lactic acid bacteria in the rumen. Pages 49-68 in The Lactic Acid Bacteria in Health and Disease. B. J. B. Wood, ed. Elsevier, New York, NY.

Stewart, C. S., H. J. Flint, and M. P. Bryant. 1997. The rumen bacteria. Pages 10-72 in The Rumen Microbial Ecosystem. P. N. Hobson and C. S. Stewart, ed. Blackie Academic \& Professional, London, UK.

Tamminga, S., and A. M. Van Vuuren. 1988. Formation and utilization of end products of lignocellulose degradation in ruminants. Anim. Feed Sci. Technol. 21:141-159.

Tamminga, S., A. M. Van Vuuren, C. J. van der Koelen, R. S. Ketelaar, and P. van der Togt. 1990. Ruminal behaviour of structural carbohydrates, non-structural carbohydrates and crude protein from concentrate ingredients in dairy cows. Neth. J. Agric. Sci $38: 513-526$

Thomas, C. 2004. Feed into Milk: A New Applied Feeding System for Dairy Cows. Nottingham University Press, Nottingham, UK.

Thornley, J. H. M., and J. France. 2007. Mathematical Models in Agriculture: Quantitative Methods for the Plant, Animal and Ecological Sciences. Rev. 2nd ed. CAB International, Wallingford, UK.

Van Vuuren, A. M., S. Tamminga, and R. S. Ketelaar. 1990. Ruminal availability of nitrogen and carbohydrates from fresh and preserved herbage in dairy cows. Neth. J. Agric. Sci. 38:499-512.

Waldo, D. R., and L. H. Schultz. 1956. Lactic acid production in the rumen. J. Dairy Sci. 39:1453-1460.

Wanapat, M., P. Gunun, N. Anantasook, and S. Kang. 2014. Changes of rumen $\mathrm{pH}$, fermentation and microbial population as influenced by different ratios of roughage (rice straw) to concentrate in dairy steers. J. Agric. Sci. http://dx.doi.org/10.1017/ S0021859613000658.

Williams, A. G., and G. S. Coleman. 1997. The rumen protozoa. Pages 73-139 in The Rumen Microbial Ecosystem. 2nd ed. P. N. Hobson and C. S. Stewart, ed. Blackie Academic and Professional, London, UK.

Williams, V. J., and D. D. S. Mackenzie. 1965. The absorption of lactic acid from the reticulo-rumen of the sheep. Aust. J. Biol. Sci. 18:917-934.

Xu, Y., and Z. Ding. 2006. A model for exploring lactic acidosis: 2. Model evaluation and validation. Belg. J. Zool. 136:125-135.

Zebeli, Q., J. Dijkstra, M. Tafaj, H. Steingass, B. N. Ametaj, and W. Drochner. 2008. Modeling the adequacy of dietary fiber in dairy cows based on the responses of ruminal $\mathrm{pH}$ and milk fat production to composition of the diet. J. Dairy Sci. 91:2046-2066. 